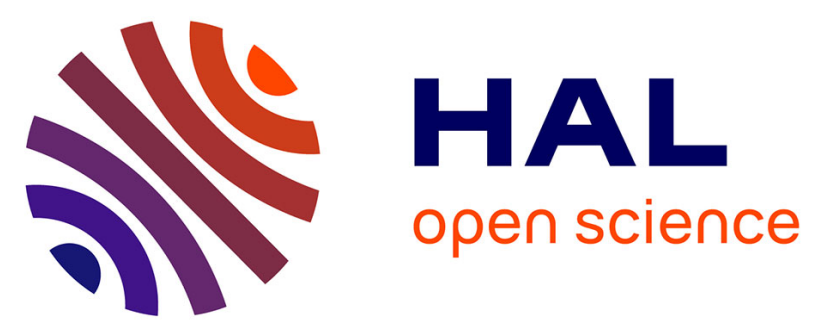

\title{
Enhanced immunological and detoxification responses in Pacific oysters, Crassostrea gigas, exposed to chemically dispersed oil
}

\author{
Andrea Luna-Acosta, R. Kanan, Stéphane Le Floch, Valérie Huet, Philippe \\ Pineau, Paco Bustamante, Hélène Thomas-Guyon
}

\section{To cite this version:}

Andrea Luna-Acosta, R. Kanan, Stéphane Le Floch, Valérie Huet, Philippe Pineau, et al.. Enhanced immunological and detoxification responses in Pacific oysters, Crassostrea gigas, exposed to chemically dispersed oil. Water Research, 2011, 45 (14), pp.4103-4118. 10.1016/j.watres.2011.05.011. hal00616692

\section{HAL Id: hal-00616692 \\ https://hal.science/hal-00616692}

Submitted on 23 Aug 2011

HAL is a multi-disciplinary open access archive for the deposit and dissemination of scientific research documents, whether they are published or not. The documents may come from teaching and research institutions in France or abroad, or from public or private research centers.
L'archive ouverte pluridisciplinaire HAL, est destinée au dépôt et à la diffusion de documents scientifiques de niveau recherche, publiés ou non, émanant des établissements d'enseignement et de recherche français ou étrangers, des laboratoires publics ou privés. 
2 to chemically dispersed oil

3

4 Luna-Acosta, A. a, ${ }^{*}$, Kanan, R. ${ }^{b}$, Le Floch, S. ${ }^{b}$, Huet, V. ${ }^{a}$, Pineau P. ${ }^{\text {a }}$, Bustamante, P. ${ }^{\text {a }}$, Thomas-Guyon, $5 \quad \mathrm{H}^{\mathrm{a},{ }^{*}}$

6

$7{ }^{a}$ Littoral Environnement et Sociétés (LIENSs), UMR 6250, CNRS-Université de La Rochelle, 2 rue 8 Olympe de Gouges, F-17042 La Rochelle Cedex 01, France

9 b Centre de Documentation, de Recherche et d'Expérimentations sur les Pollutions Accidentelles des 10 Eaux (CEDRE), 715 Rue Alain-Colas, CS41836-F-29218 Brest Cedex 2, France

* Corresponding authors: A. Luna-Acosta and H. Thomas-Guyon Littoral Environnement et Sociétés (LIENSs), UMR 6250, CNRS-Université de La Rochelle, 2 rue Olympe de Gouges 
Abstract: The aim of this study was to evaluate the effects of chemically dispersed oil on an economically and ecologically important species inhabiting coasts and estuaries, the Pacific oyster Crassostrea gigas. Studies were carried out with juveniles, known to generally be more sensitive to environmental stress than adults. A set of enzyme activities involved in immune defence mechanisms and detoxification processes, i.e. superoxide dismutase (SOD), catalase, glutathione peroxidase (GPx), catecholase-type phenoloxidase (PO), laccase-type PO and lysozyme were analysed in different oyster tissues, i.e. the gills, digestive gland and mantle, and in the plasma and the haemoycte lysate supernatant (HLS) of the haemolymph. Results indicated that total PAH body burdens were 2.7 times higher in the presence than in the absence of the chemical dispersant. After 2 days of exposure to chemically dispersed oil, alkylated naphthalenes accounted for $55 \%$ of the total PAH body burden, whereas alkylated fluorenes and alkylated dibenzothiophenes accounted for $80 \%$ when the chemical dispersant was absent. Importantly, a higher number of enzyme activities were modified when oil was chemically dispersed, especially in the plasma and gills. Moreover, independently of the presence or absence of chemical dispersant, oil exposure generally inhibited enzyme activities in the gills and plasma, while they were generally activated in the mantle and haemocytes. These results suggest that the gills and plasma constitute sensitive compartments in C. gigas, and that mantle and haemocytes may play an important role in protection against xenobiotics. Among the six enzyme activities that were analysed in these body compartments, five were modulated in the chemical dispersion (CD) treatment while only half of the enzyme activities were modulated in the mechanical dispersion treatment. Furthermore, CD treatment effects were often observed following exposure, but also during depuration periods. These results suggest that immune and/or detoxification responses are likely to be affected when dispersants are used to treat oil spills in shallow waters.

Key words: chemical dispersion, oil spill, bivalve, defence mechanisms, tissue-dependent response 


\section{Introduction}

The biological and economical consequences of numerous accidental oil spills that have occurred during the last 40 years are concrete proof of the need to develop reliable oil spill countermeasures. Large oil spills (> 100 tonnes) represent only $6 \%$ of the total introduction of oil into the environment (NCR, 2003). Indeed, most oil spills are relatively small $\left(\sim 1 \mathrm{~m}^{3}\right)$. They occur close to the shore and oil slicks hit shorelines relatively quickly. As a result of the Torrey Canyon incident, where large amounts of toxic dispersants were used and caused severe long-term biological impacts, research efforts have focused on the mechanical clean-up and containment of floating oil. However, these types of techniques in special areas, such as estuaries and closed bays, can also cause additional harm to oil-impacted zones (Marchand, 1998). During the same period, chemical dispersants evolved from first generation products, effective but highly toxic, to third generation products, with low toxicity and high biodegradability. Chemical dispersants are complex mixtures, primarily containing surfactants and solvents, which reduce the interfacial tension at the oil-water interface, and therefore facilitate the downward mixing of oil into the water (Canevari, 1973; Li and Garrett, 1998). In this way, oil can be dispersed to concentrations below toxicity threshold limits (Lessard and DeMarco, 2000; Page et al., 2000), become more accessible to hydrocarbon-degrading bacteria (Venosa and Zhu, 2003), and have a lower impact on shorelines. Moreover, third generation dispersants are considered non-toxic and biodegradable. Unfortunately, little is known about the behavior and effects of dispersed oil in the nearshore environment (ASTM Committee, 1984). Indeed, because of the higher exposure of organisms to petroleum compounds that may be triggered by the use of chemical dispersants in zones with low water-column depth, e.g. coastal areas and estuaries, most countries that allow the use of dispersants have strict rules: minimum water depth (normally $20 \mathrm{~m}$ ), minimum current speed (normally 1 meter per second), and minimum distance from the shore or from offshore islands (normally $2 \mathrm{~km}$ ) (Ramachandran et al., 2004). Recently, a Net Environmental Benefit Analysis (NEBA) carried out by Baca et al. (2006) on a 20-year field study, revealed the lack of long-term environmental impact of dispersed oil in nearshore tropical areas. However, dispersants are a wide-ranging group of chemicals with varying chemical properties and related toxicities. Therefore, many questions remain unanswered about the possible direct or indirect effects of 
their use in other nearshore zones, in response to oil spills, where human activities are heavily concentrated, such as in the case of the Transocean Deepwater Horizon oil rig explosion.

Coasts and estuaries are considered to be sensitive areas since they provide habitats for a large number of organisms, constitute nursery grounds for juveniles of several commercially important species, and bear very high productivity. Sessile and filter-feeder organisms inhabiting these zones, such as the Pacific oyster Crassostrea gigas (Thunberg, 1753), are constantly in contact with various chemical molecules. Environmental stress from pollutants is likely to be an important determining factor in weakening defence mechanisms in these organisms and therefore promoting the occurrence or increase in diseases, particularly at early life stages, i.e. larvae and juveniles (Perdue et al., 1981; Lacoste et al., 2001). Among immune defence mechanisms in bivalves, antioxidant enzyme activities, e.g. superoxide dismutase (SOD), catalase, glutathione peroxidase (GPx), and enzyme activities involved in humoral innate defences, e.g. phenoloxidase (PO) and lysozyme, have been shown to be modulated by the presence of several types of pollutants (Verlecar et al., 2007; Bado-Nilles et al., 2008; Stabili and Pagliara, 2009). In this respect, these responses have been shown to be tissue-dependent (Cheung et al., 2001; Luna-Acosta et al., 2010a).

In this general context, the aim of this study was to experimentally assess 1) the bioaccumulation and 2) the effects of chemically-dispersed oil on immune defence and/or detoxification mechanisms, i.e. SOD, catalase, GPx, catecholase- and laccase-type PO, and lysozyme activities of Pacific oyster C. gigas juveniles. For this purpose, enzyme activities were determined in different tissues, i.e. gills, digestive gland, mantle, and in the haemocytes and plasma, or acellular fraction, of the haemolymph. To this end, comparisons were made between oysters exposed to oil subjected to chemical dispersion (CD) or mechanical dispersion (MD), to the water soluble fraction of the oil (WSF) and to the dispersant alone (D).

\section{Material and methods}

\subsection{Chemicals}

Oil • A Brut Arabian Light crude oil (BAL 110) was used for this study. The crude oil was topped at $110^{\circ} \mathrm{C}$ to remove the most volatile components, in order to simulate the natural weathering of the oil after 
its release at sea (evaporation of most volatile components), before it reaches coastal zones. BAL 110 possesses the following physico-chemical characteristics, similar to the oil spilled by the Amoco Cadiz in 1978: density of 0.860 at $20^{\circ} \mathrm{C}$, viscosity of $60 \mathrm{mPa}$ s at $15^{\circ} \mathrm{C}, 12 \%$ polar compounds, $34 \%$ aromatic hydrocarbons and 54\% saturated hydrocarbons.

Dispersant $\bullet$ The chemical dispersant used in this study was selected following an evaluation carried out by the Centre of Documentation, Research and Experimentation on Accidental Water Pollution (Cedre), which defines it as 1) effective for use in the marine environment, 2) non-toxic at the concentration recommended by the manufacturer Total Fluides (i.e. 5\% v/v) and (3) biodegradable. Its physicochemical characteristics were not available for reasons of confidentiality.

\subsection{Biological material}

Pacific oyster $C$. gigas juveniles (3-4 cm in height, less than 1 year old) were purchased from the hatchery France Naissain, located in Bouin (France). The oysters were acclimatised in the laboratory at $15 \pm 1^{\circ} \mathrm{C}$ for two weeks before starting the experiments. They were fed daily with an algal diet $\left(5 \times 10^{4} \mathrm{cell} \mathrm{ml}^{-1}\right)$ composed of Heteroskeletonema sp. (Bacillariophyceae) purchased from the hatchery SATMAR (Normandie, France).

\subsection{Experimental design}

The experiment, consisting of an exposure period followed by a depuration period, was carried out three times to provide analysis replicates.

Experimental system - The experimental system consisted of $300 \mathrm{~L}$ static water tanks. Because of the hydrophobic character of the oil, a funnel (at the surface of each tank) was connected to a submersed Johnson L450 water pump (at the bottom of the tank), in order to maintain the mixture of oil and dispersant as a homogenous solution. Preliminary tests confirmed that total petroleum hydrocarbon concentrations in the water column were depth-independent, suggesting that small petroleum droplets were homogeneously dispersed in the water column (data not shown). The oxygen saturation of water in each tank was maintained at around $96 \%$ by a compressor that injected air via an air stone. The 
experimental system was placed in a thermoregulated greenhouse, in order to maintain the temperature of the exposure studies at $15 \pm 1{ }^{\circ} \mathrm{C}$.

Exposure $\bullet$ One experimental system was used per condition, making a total of five experimental systems. Thirty oysters were transferred into each experimental system. The different exposure conditions are summarized in Table 1. The exposure period lasted 2 days. The seawater used for this study (pH: $7.95 \pm$ 0.05, salinity: $35.2 \pm 0.1$ p.s.u.) was provided by Oceanopolis, Brest (France). This seawater was treated by UV-light and filtrated at $0.45 \mu \mathrm{m}$ before use. In the first tank, the control exposure condition was set up with clean seawater. For the amount of BAL selected, the aim of this study was to obtain a concentration of dispersed oil in the same rank than those reported in situ, following an oil spill, such as reported by Lunel (1995) following the Braer oil spill. Thus, in the second tank, the chemical dispersion (CD) condition was set up by pouring $20 \mathrm{~g}$ of BAL 110 and the volume of dispersant recommended by the manufacturer, i.e. $1.2 \mathrm{~g}$ of dispersant, into the funnel of the experimental system. In the third tank, the mechanical dispersion (MD) condition was set up by pouring $20 \mathrm{~g}$ of BAL 110 into the funnel. In the fourth tank, the toxicity of molecules that naturally dissolve in seawater was tested, by exposing oysters to a water-soluble fraction (WSF) of BAL 110. To obtain the WSF, a plastic circle was set on the surface of the seawater in the experimental system. The BAL $110(20 \mathrm{~g})$ was then poured into the plastic circle, in order to contain the oil slick at the surface, without mixing. The oysters were therefore only exposed to the soluble fraction of the oil, i.e. free of particles of bulk material, and, contrary to the wateraccommodated fraction (WAF), free of soluble and volatile compounds that can naturally evaporate (Anderson et al., 1974; Singer et al., 2000). In the fifth tank, an internal control for the CD condition was set up by pouring $1.2 \mathrm{~g}$ of chemical dispersant into the funnel (i.e., dispersant condition, D). All experimental systems contained a funnel connected to a submersed water pump. All exposure media were added to the tanks $13 \mathrm{~h}$ before adding the oysters, the time needed to obtain a relatively stable oil concentration in the water column. The oysters were not fed during the exposure period.

Depuration - Ten oysters per treatment condition were placed in a decontamination tank, located in the thermoregulated greenhouse $\left(\mathrm{T}=15 \pm 1^{\circ} \mathrm{C}\right)$ and containing clean seawater, for a recovery period of 15 days. The oysters were fed daily with an algal diet $\left(5 \times 10^{4} \mathrm{cell} \mathrm{ml}^{-1}\right)$ composed of Heteroskeletonema sp. (Bacillariophyceae). 


\subsection{Sampling procedure}

Pooled gills, digestive glands, mantles, haemocyte fraction and plasma of ten oysters were used for each replicate sample, and three replicates were prepared per treatment. After opening the oyster shells by cutting off the adductor muscle, approx. $0.3-0.5 \mathrm{ml}$ of haemolymph was withdrawn from the pericardial cavity using a $1-\mathrm{ml}$ syringe equipped with a needle $(0.9$ × $25 \mathrm{~mm})$. Haemolymph samples were centrifuged at $260 \mathrm{x} \mathrm{g}$ for $10 \mathrm{~min}$ at $4^{\circ} \mathrm{C}$ in order to separate the cellular (haemocytes) fraction from the plasma. The gills, digestive gland and mantle were removed from the soft tissues and homogenized at $4^{\circ} \mathrm{C}$ in $0.1 \mathrm{M}$ Tris $\mathrm{HCl}$ buffer pH $7.0\left(0.45 \mathrm{M} \mathrm{NaCl}, 26 \mathrm{mM} \mathrm{MgCl}_{2}, 10 \mathrm{mM} \mathrm{CaCl}_{2} ; 0.5 \mathrm{ml}\right.$ of buffer.g ${ }^{-1}$ of fresh weight for the gills and the mantle, and $1 \mathrm{ml}^{-\mathrm{g}^{-1}}$ of fresh weight for the digestive gland), using an Ultra Turrax (T25 basic, IKA-WERKE) and a Thomas-Potter homogenizer (IKA-Labortechnik RW 20.n, size $0.13-0.18 \mathrm{~mm}, \mathrm{BB})$. The homogenates were centrifuged at $10000 \mathrm{x} \mathrm{g}$ for $10 \mathrm{~min}$ at $4^{\circ} \mathrm{C}$. The resulting supernatant was collected for enzymatic studies.

\subsection{Biochemical analysis}

Superoxide dismutase assay $\bullet$ SOD was determined as described previously (Luna-Acosta et al., 2010a) based on competition of SOD with iodonitrotetrazolium (INT) for dismutation of superoxide anion $\left(\mathrm{O}_{2}^{-}\right)$. In the presence of $\mathrm{O}_{2}^{-}$, INT is reduced into a red formazan dye that can be measured at $505 \mathrm{~nm}$ at $25^{\circ} \mathrm{C}$ (Kit Ransod SD 125, Randox, France). One unit of SOD is defined as the amount of enzyme that promotes a $50 \%$ decrease in the rate of INT reduction.

Glutathione peroxidase assay • GPx activity was determined as described previously (Luna-Acosta et al., 2010a). In the presence of glutathione reductase and substrates (i.e. reduced glutathione and cumene hydroperoxide), the decrease of absorbance at $340 \mathrm{~nm}$ was proportional to the reduction of the oxidised glutathione by NADPH, $\mathrm{H}^{+}$(Kit Ransel RS 504, Randox, France). One unit of GPx oxidises $1 \mu$ mol of $\mathrm{NADPH}\left(\varepsilon_{\mathrm{NADPH}}=6.22 \mathrm{mM}^{-1} \mathrm{~cm}^{-1}\right)$ per minute.

Catalase assay $\bullet$ Catalase activity was determined according to the method of Fossati et al. (1980). This method is based on the measurement of the hydrogen peroxide substrate remaining after the action of catalase. First, catalase converts hydrogen peroxide into water and oxygen and then this enzymatic 
reaction is stopped with sodium azide. An aliquot of the reaction mix was then assayed for the amount of hydrogen peroxide remaining using a colorimetric method (Kit Catalase CAT-100, Sigma).

Catecholase-type and laccase-type phenoloxidase assay $\bullet$ Catecholase- and laccase-type phenoloxidase (PO) activities were determined according to the method described previously (Luna-Acosta et al., 2010b). For PO assays, $100 \mathrm{mM}$ of dopamine or $50 \mathrm{mM}$ of PPD were used as substrates and the increase of absorbance at 490 and $420 \mathrm{~nm}$ was monitored for 4 and $2 \mathrm{~h}$ for catecholase- and laccase-type PO activity, respectively. Nonenzymatic oxidation by the substrate was monitored in wells without oyster sample and subtracted from oxidation of the substrate with oyster sample. One unit of catecholase- and laccase-type PO activities corresponds to the amount of enzyme that catalyzes the production of $1 \mu$ mole of product ( $\varepsilon=3300 \mathrm{M}^{-1} \mathrm{~cm}^{-1}$ and $43160 \mathrm{M}^{-1} \mathrm{~cm}^{-1}$, respectively), per minute.

Lysozyme assay • Lysozyme was determined as described previously (Luna-Acosta et al., 2010a). The lysozyme assay was done in triplicate for each sample and compared to hen egg white lysozyme standards (2.5-20 $\left.\mathrm{g} \mathrm{m} \mathrm{m}^{-1}\right)$, in the presence of Micrococcus lysodeikticus (Sigma-Aldrich, France). One unit of lysozyme corresponds to the amount of enzyme that diminishes absorbance at $450 \mathrm{~nm}$ by 0.001 per minute at $\mathrm{pH} 7.0$, at $25^{\circ} \mathrm{C}$.

Protein assay • All activities were expressed in relation to the protein concentration measured according to the Lowry method with slight modifications, using bicinchoninic acid and copper sulphate 4\% (Smith et al., 1985). Serum albumin was used as protein standard (Sigma-Aldrich, France). All enzyme activities were measured in the gills, digestive gland, mantle, plasma and HLS, except for lysozyme that was not measured in the HLS, making a total of 29 enzymatic analyses.

\subsection{Chemical analysis in oysters}

The levels of polycyclic aromatic hydrocarbons (PAHs) in oysters were determined with a Varian Saturn 2100 T GC-MS device, using the procedure of Baumard et al. (1997) with some modifications. Three pools of five oysters were analysed per treatment. Prior to extraction, each oyster sample was homogenized using an Ultra Turrax (Janke and Kunkel, IKA ${ }^{\circledR}$-Labortechnik). $150 \mu 1$ of perdeuterated internal standards (CUS-7249, Ultra Scientific, Analytical solutions) were added to $3 \mathrm{~g}$ of homogenized oyster samples and the mixtures obtained were digested for $4 \mathrm{~h}$ under reflux in $50 \mathrm{ml}$ of an ethanolic 
solution of potassium hydroxide ( $2 \mathrm{M}$, Fisher Chemicals). After cooling, settling and addition of $20 \mathrm{ml}$ of demineralised water, the digest was extracted in a $250 \mathrm{ml}$ funnel twice with $20 \mathrm{ml}$ of pentane (Carlo Erba Reactifs, SDS). The extract was evaporated with a TurboVap 500 concentrator (Zyman, Hopkinton, MA, USA, at 880 mbar and $50{ }^{\circ} \mathrm{C}$ ) to obtain $1 \mathrm{ml}$ of concentrated extract. The purification of the extract was performed by transfer to a silica column ( $5 \mathrm{~g}$ of silica). Hydrocarbons were eluted with $50 \mathrm{ml}$ of pentane: dichloromethane (80:20, v:v, SDS) and concentrated to $200 \mu \mathrm{l}$ by means of a TurboVap 500 concentrator (Zyman, 880 mbar, $50^{\circ} \mathrm{C}$ ). Aromatic compounds were analysed by GC-MS, with a detection limit of $0.005 \mu \mathrm{g} \mathrm{g}^{-1}$ of dry weight, and PAHs were quantified relative to the perdeuterated internal standards introduced at the beginning of the sample preparation (Roy et al., 2005). Five perdeuterated standard compounds, i.e. Naphthalene d8, Biphenyl d10, Phenanthrene d10, Chrysene d12, and Benzo[a]pyrene d12, representative of all the PAHs analysed, were used as internal standards. A total of 20 parent PAHs and 25 alkylated compounds were quantified. The PAH recovery was $>60 \%$ and the relative standard deviation (RSD, i.e. (standard error / mean x 100) was < $15 \%$.

\subsection{Statistical analysis}

All values are reported as mean \pm standard deviation (SD). Statistical analysis was carried out with STATISTICA 7.0. Values were tested for normality (Shapiro test) and homogeneity of variances (Bartlett test). In some cases, logarithmic transformations $\left(\log _{10}\right)$ were used to meet the underlying assumptions of normality and homogeneity of variances. Two-way nested MANOVA were used to analyse results, with treatment and period as fixed factors, and pool as a random factor. The period factor corresponds to the exposure period and the depuration period. Pool was nested within each combination of treatment and time (Zar, 1984). When the null hypothesis $\left(\mathrm{H}_{0}\right.$ : no difference between treatments or within treatment at different time intervals) was rejected, significant differences were tested using Tukey's HSD test. For non normal values, i.e. to compare oysters' PAH content between different treatments, a Kruskal-Wallis test was used, followed by a Dunn's multiple comparisons test. Statistical significance was determined as being at the level of $p<0.05$. The relationships between body burdens for the different PAH categories (HMW PAHs, LMW PAHs, parent PAHs and alkylated PAHs) and the responses of the enzyme activities were analysed using principal component analysis (PCA) and redundancy analysis (RDA) (Leps and 
Smilauer, 1999). Separate analyses were performed for the different organs. Data for enzyme activities were centered and standardized before analysis. PCA and RDA were performed using CANOCO for Windows ${ }^{\circledR}$ software package, Version 4.5 (Center for Biometry, Wageningen, The Netherlands). For RDA analyses, the significance of the relationship between enzyme activities and PAH body burdens were tested using a global Monte Carlo permutation test.

\section{Results}

\subsection{Chemical analyses}

After 2 days of exposure, PAHs had been efficiently bioaccumulated in the soft tissues of $C$. gigas. The total PAH content in oysters ( $\sum$ PAHs) was equal to $7 \pm 1,530 \pm 75,198 \pm 22,56 \pm 50$ and $8 \pm 3 \mu \mathrm{g} \mathrm{g}^{-1}$ dry weight for the control, the chemically dispersed oil (CD), the mechanically dispersed oil (MD), the water soluble fraction (WSF) and the dispersant (D) treatments, respectively. Significant differences were found between the control and the $\mathrm{CD}$ or the $\mathrm{MD}$, but not with the WSF conditions $\left(\mathrm{F}_{4,15}=12.83, \mathrm{p}=\right.$ 0.01). This lack of significant difference could be explained by the high variation in total PAH levels in the WSF condition. Importantly, the total PAH content in oysters in the CD condition was almost 3 times higher than in the MD condition.

After 15 days of depuration, the $\sum$ PAHs was equal to $3 \pm 0,15 \pm 6,14 \pm 6,2 \pm 0$ and $2 \pm 2 \mu \mathrm{g} \mathrm{g}^{-1}$ dry weight in control, CD, MD, WSF and D treatments, respectively. Even if the PAH content in oysters had decreased by 97 and 93\% in CD and MD conditions, respectively, it remained significantly higher than the control condition $\left(\mathrm{F}_{4,15}=10.27, \mathrm{p}=0.03\right)$.

Independently of time and treatment, light PAHs ( $\leq 3$ rings) and their alkylated homologues accounted for at least $90 \%$ of the total PAHs in oyster tissues (Fig. 1). After 2 days of exposure to the CD condition, alkylated naphthalenes (NaF), alkylated dibenzothiophenes (DBT) and alkylated fluorenes (Fl) accounted for most of the PAH content in oyster soft tissues with $55 \pm 6,19 \pm 1,18 \pm 8 \%$ for alkylated NaF, alkylated DBT and alkylated Fl, respectively (Fig. 1). In the MD condition, alkylated DBT and alkylated Fl accounted for most of the PAH content in the oysters' soft tissues, representing $38 \pm 2$ and $40 \pm 2 \%$ of the total PAHs, respectively. Alkylated DBT $(22 \pm 0 \%)$ and alkylated Fl $(53 \pm 0 \%)$ also accounted for a large proportion of the PAH content in the oysters' soft tissues in the WSF condition. For the D condition, 
alkylated DBT $(45 \pm 6 \%)$ and anthracene $(30 \pm 7 \%)$ accounted for most of the PAH content in oyster soft tissues.

After 15 days of depuration, alkylated DBT were the predominant PAH compounds in oyster tissues of the CD, MD, WSF and D conditions, representing $56 \pm 19 \%, 48 \pm 7 \%, 40 \pm 5 \%$ and $50 \pm 16 \%$ of the total PAHs, respectively (Fig. 1).

\subsection{Enzymatic analysis}

Overall, no significant differences in enzymatic activities were observed between the control conditions from both exposure and depuration periods, whatever the tissue (Figs. 2-7). In contrast, all enzyme activities were affected by both treatment and period, independently of the considered tissue, except for catecholase and laccase activities in the mantle, which were only affected by the treatment (Figs. 5 and 6). No significant effect was observed for treatment for lysozyme activity in the gills and plasma (data not shown).

After 2 days of exposure for the CD condition, and relative to the control condition, catalase (Fig. 3) and GPx (Fig. 4) activities were completely inhibited and laccase activity (Fig. 6) was 1.4-fold higher in the gills. SOD (Fig. 2) and GPx (Fig. 4) activities were 30\% and 50\% lower in the digestive gland, respectively. Catalase activity (Fig. 3) was $75 \%$ lower in the mantle. Interestingly, results from the HLS and the plasma differed. While no significant effect was observed in the HLS, SOD activity (Fig. 2) was 2-fold higher and catalase (Fig. 3) and laccase (Fig. 6) activities were completely inhibited in the plasma. For the MD condition, SOD (Fig. 2) and laccase (Fig. 6) activities were 2.5-fold and 1.4-fold higher in the gills, respectively. GPx activity (Fig. 4) was 1.5-fold higher in the mantle. While SOD (Fig. 2), GPx (Fig. 4), catecholase (Fig. 5) and laccase (Fig. 6) activities were 2-4-fold higher in the HLS, catalase activity (Fig. 3) was completely inhibited in the plasma. For the WSF condition, SOD (Fig. 2) and laccase (Fig. 6) activities were 2.5- and 1.7-fold higher in the gills, respectively. SOD (Fig. 2) and catecholase (Fig. 5) activities were 4- and 2-fold higher in the HLS, respectively. It is important to notice that the dispersant alone (D condition), which is considered as a harmless product, also modulated different enzyme activities in C. gigas: laccase activity (Fig. 6) was 1.4-fold higher in the gills; SOD (Fig. 2) and lysozyme 
(Fig. 7) activities (Fig. 2) were 70 and 55\% lower in the digestive gland, respectively, and SOD (Fig. 2), catecholase (Fig. 5) and laccase (Fig. 6) activities were 2.5- to 3-fold higher in the HLS.

After 15 days of depuration, some activities returned to control levels, depending on the tissue and the treatment. In some tissues and for some activities, effects were observed only at this period, e.g. SOD activity (Fig. 2) was 1.3-fold higher in the mantle for the MD condition; catalase activity (Fig. 3) was 2to 2.5-fold higher in the digestive gland for the CD, WSF and D conditions; SOD activity (Fig. 2) was 1.3-fold higher for the MD condition; lysozyme activity (Fig. 7) was 1.4- to 1.6-fold higher for the CD, WSF and D conditions in the mantle; catecholase activity (Fig. 5) was inhibited by 20 to $30 \%$ in the plasma for the $\mathrm{CD}, \mathrm{MD}$ and WSF conditions, and 1.4-fold higher in the D condition.

In addition to these results, a significant treatment, but not period, effect was observed in the mantle for catecholase (Fig. 5) and laccase (Fig. 6) activities. In this tissue, catecholase activity was inhibited by $20 \%$ for the $\mathrm{CD}$ and MD conditions and laccase activity was 1.2-fold higher for the CD and the D conditions.

\subsection{Relationships between PAH contents in oyster soft tissues and enzyme activities}

At the end of the exposure period, significant correlations were observed between different enzyme activities and PAH contents in oyster soft tissues and responses varied according to the tissue that was analysed. The results of PCA and RDA are presented in Fig. 8 and Table 2, respectively. RDA indicated PAH body burdens as the significant variable explaining $49 \%, 43 \%, 43 \%, 39 \%, 44 \%$ of total variation in enzyme activities in the gills, digestive gland, mantle, plasma and HLS, respectively. Enzyme activities in the gills, plasma and mantle were significantly correlated to parent PAHs. Enzyme activities in the plasma were also significantly correlated to LMW PAHs. Four out of six enzyme activities analysed in the gills and plasma were negatively correlated to body burdens of the various PAH categories: catalase, GPx, lysozyme, and catecholase or laccase, in the gills and plasma, respectively (Fig. 8, Table 2). SOD, GPx, catecholase and lysozyme in the mantle were positively correlated to body burdens of the various PAH categories (Fig. 8, Table 2). Four out of five enzyme activities analysed in the HLS, i.e. SOD, GPx, catecholase and laccase, were negatively correlated to body burdens of the various PAH categories, but were positively correlated to parent PAHs (Fig. 8, Table 2). Enzyme activities in the digestive gland were 
significantly correlated to HMW PAHs. Five out of six enzyme activities analysed in the digestive gland were positively correlated to body burdens of the various PAH categories: SOD, catalase, catecholase, laccase and lysozyme (Fig. 8, Table 2).

\section{Discussion}

\subsection{PAH bioaccumulation and depuration in oyster tissues}

The aim of this study was to assess 1) the bioaccumulation and 2) the effects of chemically dispersed hydrocarbons on a species inhabiting coastal and estuarine zones, the Pacific oyster $C$. gigas. This marine bivalve is a good indicator of the presence and bioavailability of oil in the water column and benthic sediments. In this species, bioconcentration factors (BCF) of petroleum hydrocarbons range from 10 to 50000 (Michel and Henry, 1997), so even low levels of exposure are likely to be detectable in oyster tissues. PAHs, with high octanol-water partition coefficients $\left(\log \mathrm{K}_{\mathrm{ow}}>3.5\right)$, are readily taken up by organisms (Meador, 2003). Thus, evaluating PAH bioaccumulation plays an important part in assessing the risk that chemical dispersants are likely to pose to marine organisms inhabiting coasts and estuaries, especially carcinogenic, mutagenic or teratogenic PAHs. Because no PAH measurements were carried out in seawater, we were not able to calculate $\mathrm{BCF}$, but PAH body burden analysis was conducted in oyster soft tissues. Results showed that, independently of the treatment (i.e. CD, MD, WSF or D), heavy PAHs were poorly accumulated in oyster tissues (0-3\% of the total PAH content), while light PAHs and mainly their alkylated homologues, which are generally more toxic than the parent compounds, were present in large proportions in all the treatment conditions. Indeed, PAHs with low molecular weight $(\leq 178.2$ $\mathrm{g} \mathrm{mol}^{-1}$ ) such as NaF, DBT and Fl are more likely to be bioaccumulated due to high water solubility and higher bioavailability for organisms (Neff, 2002).

A high heterogeneity in PAH body burden was observed for the WSF treatment. The WSF corresponds to hydrocarbon molecules that are liable to naturally dissolve, meaning that the solution can be considered as homogeneous. Therefore, the heterogeneity of results for the WSF treatment suggests that 1) organisms depurate at different rates and/or that 2) organisms accumulate at different rates (Neff, 2002).

Interestingly, for the same amount of dispersed oil with (CD condition) or without (MD condition) a chemical dispersant, and for the same exposure time, i.e. 2 days, oysters bioaccumulated approximately 
2.7 times more PAHs in the presence of the chemical dispersant, showing that the dispersant increased the bioavailability of PAHs and thus their uptake rate in $C$. gigas. The bioaccumulated PAH compounds were completely different between both $\mathrm{CD}$ and MD conditions. In the CD condition, 55\% of the total PAH content was composed of high alkylated NaF. These compounds were poorly bioaccumulated in the MD and WSF conditions (Fig. 1), whereas alkylated Fl and alkylated DBT represented between 70 and $80 \%$ of the total PAH content (Fig. 1). Our results for the CD condition but not for the MD condition are in agreement with a recent study carried out on the Iceland scallop Chlamys islandica where C3-NaF accounted for a large proportion of the PAHs that were accumulated in the tissues after 15 days of exposure to mechanically dispersed oil (Hannam et al., 2009). In the present study, the exposure experiment was carried out for only 2 days, and, since uptake rate constants of PAHs in bivalves generally increase with molecular weight or molecular complexity (McLeese and Burridge, 1987), it cannot be excluded that a longer exposure period would result in a higher alkylated $\mathrm{NaF}$ uptake in oyster tissues. Nonetheless, our results clearly demonstrated that the presence of the chemical dispersant increased the bioaccumulation rate of alkylated $\mathrm{NaF}$ in oyster soft tissues. However, the processes that could alter 1) the bioconcentration and/or 2) the type of components accumulated, when oil is chemically dispersed, have been poorly described in the scientific literature. A possible contributing factor for bioaccumulation of some components is that dispersing spilled oil converts the oil from a surface slick to a plume of small oil droplets dispersed in the water column. These oil droplets might be more easily ingested by filter-feeding organisms, such as oysters (Baussant et al., 2001). Additionally, particles trapped on the oysters' gills are directed into the gut and later incorporated into endocytic vacuoles in the digestive gland. Oil particles retained in intracellular vacuoles can also be assimilated to the tissue lipids (Baussant et al., 2001). Thus, in the CD treatment, a significant amount of the larger PAHs bound to particles could be retained and accumulated in intracellular vacuoles or in tissue lipids during the exposure period.

After 15 days of depuration, more than $90 \%$ of the PAH burden had been depurated from oysters' soft

373 tissues. Even if PAH contents in $\mathrm{CD}$ and MD conditions were still significantly higher than the control 374 condition, this result clearly shows that oysters can eliminate high quantities of PAHs very rapidly. 
period. This result is in agreement with a previous study carried out on mussels (Gilfillan et al., 1984). Among PAHs, alkylated DBTs were the most persistent PAHs in all treatments (Fig. 1). This result is in agreement with Berthou et al. (1987) who report that DBT persist in oyster tissues for at least one year. As in the present study, C3-DBT was among the most persistent PAHs (Berthou et al., 1987), raising questions about its potential toxic effects. Further studies are therefore needed in order to assess the longterm toxicity of this compound.

\subsection{Effect on enzyme activities}

Disease emergence and organism survival are determined partly by the condition of the immune system. Therefore, the measurement of defence mechanisms can provide important early warning signals of the sub-lethal effects of exposure to contaminants and the susceptibility of animals to infectious diseases (Hannam et al., 2009).

Bivalve molluscs possess two types of innate responses: 1) cellular, i.e. phagocytosis and encapsulation; and 2) humoral, e.g. PO and lysozyme enzyme activities (Tryphonas et al., 2005). During phagocytosis, reactive oxygen species (ROS), such as the superoxide anion $\left(\mathrm{O}_{2}^{-}\right)$and hydrogen peroxide $\left(\mathrm{H}_{2} \mathrm{O}_{2}\right)$, play an important role in protection against pathogens. However, ROS can also interact with hosts' biological macromolecules which can result in enzyme inactivation, lipid peroxidation, DNA damage or cell death (Cazenave et al., 2006). The extent to which oxyradical generation produces biological damage depends on the effectiveness of antioxidant defences, such as SOD, which participates in the transformation of $\mathrm{O}_{2}{ }^{-}$ into $\mathrm{H}_{2} \mathrm{O}_{2}$ and $\mathrm{H}_{2} \mathrm{O}$, and of catalase and GPx, which participate in the transformation of $\mathrm{H}_{2} \mathrm{O}_{2}$ into $\mathrm{O}_{2}$ and $\mathrm{H}_{2} \mathrm{O}$ (Neumann et al., 2001).

Environmental contaminants, such as PAHs, can lead to the formation of ROS and enhance oxidative stress in aquatic organisms (Winston, 1991). Results from the present study showed a positive correlation between PAH contents and SOD activities. Such a relationship has already been reported for different bivalve species exposed to hydrocarbons (Sole et al., 1995; Orbea et al., 2002; Richardson et al., 2008) and suggests that hydrocarbons induce oxidative stress by producing ROS such as $\mathrm{O}_{2}^{-}$. However, in the present study, catalase and GPx activities were generally negatively correlated with different PAH body burdens. This may be due to the inhibition of enzyme synthesis by PAHs or to enzyme inactivation 
caused by high tissue contaminant concentrations (Borg and Schaich, 1983). Moreover, since GPx and catalase catalyze the transformation of $\mathrm{H}_{2} \mathrm{O}_{2}$ into $\mathrm{H}_{2} \mathrm{O}$, they may act on common substrates, and thus competition may exist for the same group of substrates (Kappus, 1985). This may explain the positive correlations of catalase activity and negative correlations of GPx activity with PAH content for the same tissues in the present study (Table 2).

Among enzymes involved in humoral immune defences in bivalves, POs are the key enzymes of melanization, participating in the entrapment of foreign material in a melanin capsule or in the direct killing of microbes by the toxic quinone intermediates produced during the melanin production cascade (Söderhäll and Cerenius, 1998). Tyrosinases, catecholases, and laccases belong to the family of POs. While tyrosinase possesses monophenolase (hydroxylation of monophenols) and catecholase (oxidation of diphenols) activities, catecholase only possesses catecholase activities and laccase possesses both catecholase and laccase activities (oxidation of o-, p- and m-diphenols and other non phenolic substrates such as diamines). In a recent study, two types of PO activity, catecholase and laccase, were detected in C. gigas (Luna-Acosta et al., 2010b). In the present study, catecholase activities were generally inhibited in the presence of hydrocarbons, except for HLS catecholase activity. These results are in agreement with other studies on $C$. gigas where exposure to hydrocarbons induced an inhibitory effect in PO activities (Bado-Nilles et al., 2008). Moreover, when using PPD as a substrate for PO assays in this study, laccase activities were generally stimulated in the presence of hydrocarbons, except for laccase activity in plasma. These results are in agreement with previous studies where the exposure of $C$. gigas to a light cycle oil (LCO) soluble fraction induced an increase in the mRNA expression of a laccase (multicopper oxidase) gene in haemocytes after 7 days of exposure (Bado-Nilles et al., 2010). Since laccases can catalyze oxidation of aromatics, such as PAHs, by an indirect mechanism involving the participation of an oxidative mediator (Dodor et al., 2004), an increase in laccase gene transcription in C. gigas may enable protection against bioaccumulated PAHs. Laccase could therefore be a potential defence biomarker candidate in ecotoxicological studies.

Lysozyme is one of the most important bacteriolytic agents against several species of Gram-positive and Gram-negative bacteria, and has been recorded for various bivalve species (McHenery et al., 1986). During phagocytosis, the release of lysosomal enzymes, such as lysozymes, participates in the 
inactivation of invading pathogens. In the present study, inhibition of lysozyme activity was observed in the digestive gland in the $\mathrm{D}$ condition. Previous studies have shown inhibition of lysozyme activity or lysozyme gene expression in organisms exposed to hydrocarbons (Boutet et al., 2004; Gopalakrishnan et al., 2009). However, in this study no lysozyme inhibition was observed in the presence of hydrocarbons, except in the digestive gland for the D condition. Activation of mantle lysozyme activity was observed during the depuration period. Although generally pollutant exposure has shown to inhibit lysozyme activity in bivalves (for review, see Giron-Perez, 2010), some studies have shown an induction of lysozyme activity (e.g., Oliver et al., 2003; Ordas et al., 2003; Hannam et al., 2009). However, to our knowledge, no studies have shown the modulation of lysozyme activity during the depuration period. The activation of this enzyme activity suggests a potential immunostimulation during the depuration period. Uptake of xenobiotics from seawater is generally accomplished by filtration over the gill structure, although diffusion through the integument may also contribute to tissue concentrations (Landrum and Stubblefield, 1991). As the organism directs seawater over the gill surface to extract oxygen, hydrophobic contaminants are very efficiently taken up because of the large surface area and lipid-rich membranes. Moreover, bivalves possess an open circulatory system and are thus continually exposed to fluctuations of environmental factors including contaminants (Cheng, 1981). As a general trend, enzyme activities in the plasma and gills were generally inhibited, especially in the CD condition (Figs. 2-7), suggesting that compartments that are the more exposed to the marine environment, such as the gills and plasma, are likely to be more affected by the presence of hydrocarbons, in comparison to tissues less exposed to the marine environment, such as the digestive gland, mantle and HLS (Cheng, 1981; Frouin et al., 2007). Enzyme activities in the digestive gland were less modulated than in the other tissues but were strongly correlated with PAH contents in this tissue, highlighting its role in xenobiotic detoxification (Chafai-El Alaoui, 1994; Chu et al., 2003).

Enzyme activities in the mantle and haemocytes, which are known to play an important role in defence mechanisms in oysters (Cheng, 1981), were generally activated in comparison to the control.

457 Among tissues that were analysed, haemolymph can be considered as a key tissue because this fluid 458 irrigates the whole body and, therefore, it can distribute contaminants and/or their metabolites throughout the organism (Cheng, 1981). Interestingly, enzyme activities differed notably from the plasma and HLS 
of the haemolymph. These differences could be due to alterations in the membrane integrity by PAHs and/or their metabolites, as suggested by in vitro and in vivo investigations in the blue mussel Mytilus edulis (Grundy et al., 1996). The extent of membrane alterations could be dependent on the physical (e.g. linear versus angular or branched configuration of isomers) and/or chemical (e.g. low molecular weight with high solubility versus high molecular weight with low solubility) properties of the compounds. In addition, modulation of enzyme activities in the plasma can be attributed to 1) normal mechanisms, such as secretion or 2) pathological features, such as cell lysis. Indeed, PAHs can cause cytolysis in haemocytes (McCormick-Ray, 1987), due to 1) a depletion or stimulation of metabolites or coenzymes, 2) an inhibition or stimulation of enzymes and other specific proteins, 3) an activation of a xenobiotic to a more toxic molecular species, or 4) membrane disturbances (for review, see Moore 1985). Cytolysis may lead to 1) an increase in haemocyte number indicating compensation for cell lysis and/or 2) the release of cell contents in the plasma and consequently, a significant increase in plasma enzyme activities. Alternatively, direct induction or repression by PAHs of humoral factors, such as lysozyme (LunaGonzalez et al., 2004) and pro-phenoloxidase (Söderhäll and Cerenius, 1998), may contribute to the modulation of enzyme activities found in the plasma.

\subsection{Effect of chemical dispersion (CD) and dispersant (D) conditions}

Increased activity of an enzyme involved in defence mechanisms can be interpreted as a response of the organism to protect itself against a non-self molecule, e.g. xenobiotics. Persistent or excessive activation can lead to overstimulation of the immune system, which can be detrimental to the organism. Inhibition of the enzyme activity can be interpreted as saturation of the system because of the presence of a xenobiotic, overpowering of antioxidant enzymes by oxygen radicals, or an immunodeficiency resulting in direct or an indirect inhibition of mechanisms that modulate this enzyme activity (Huggett et al., 1992). In both cases, changes in defencive enzymes may affect the survival of the organisms when challenged with infectious pathogens (Thiagarajan et al., 2006).

Twenty nine enzymatic analyses were carried out in this study. As a general trend and relative to the control, CD modulated a higher number of enzyme activities than $\mathrm{D}$, following the exposure period. Indeed, an equal or greater effect was observed in 13/18 (i.e. 13 out of 18) enzyme activities modulated 
by $\mathrm{CD}$ and/or D: 5/5, 2/3, 3/3, 3/3 and 0/4 enzyme activities modulated by $\mathrm{CD}$ and/or $\mathrm{D}$ in the gills, digestive gland, mantle, plasma and HLS, respectively (Figs. 2-7). When comparing CD and MD conditions, following the exposure period, CD modulated a higher number of enzyme activities than MD, relative to the control condition, with an equal or greater effect observed in 13/19 activities modulated by CD and/or MD: 4/5, 2/2, 3/4, 4/5 and 0/4 enzyme activities modulated by CD and/or MD in the gills, digestive gland, mantle, plasma and HLS, respectively (Figs. 2-6). Moreover, CD exerted an equal or greater effect in a higher number of enzyme activities in the gills and plasma in comparison to other tissues, i.e. 4/5 enzyme activities modulated by CD and/or MD (Figs. 2-6), suggesting that the gills and plasma are sensitive compartments in C. gigas. Moreover, some enzyme activities that were modulated by the CD treatment following the exposure period were also modulated following the depuration period, e.g. SOD activity in the gills, mantle and plasma (Fig. 2), or laccase activity in the plasma (Fig.6), suggesting that $\mathrm{CD}$ may exert long-term effects. Importantly, D also modulated enzyme activities, especially at the end of the depuration period, e.g. SOD activity in the plasma and HLS (Fig. 2), catalase activity in the digestive gland (Fig. 3), GPx activity in the plasma (Fig. 4), catecholase activity in the plasma and HLS (Fig. 5), laccase activity in the gills and digestive gland (Fig. 6) and lysozyme activity in the mantle (Fig. 7), suggesting that the dispersant used in the present study could also induce long-term effects, i.e. following 15 days of depuration. Our results are thus in agreement with previous studies that have shown the effects of other third generation dispersants on biological functions in marine invertebrates (Gilfillan et al., 1984; Shafir et al., 2007).

Differences between oysters from the control and the treatment conditions resided only in the presence of oil and/or dispersants in the water column (i.e. experimental devices and acclimatization conditions were identical in the control and the treatment conditions). Additionally, the D treatment (i.e. in the absence of oil) induced effects in enzyme activities such as laccase in the gills, SOD, catalase and lysozyme in the digestive gland, and SOD in the plasma, following the exposure or the depuration periods. Therefore, significant differences in biological responses between the control and the different treatments could not be considered as specific to contamination by hydrocarbons, but rather as indicators of unspecific stress in oysters, induced by chemicals (oil and/or dispersants) that have entered the organism from the water column. It is important to notice that transient effects were observed for different enzyme activities and 
thus longer periods of exposure should be studied. Moreover, not all the enzyme activities returned to control levels after the 15-day depuration period and thus longer depuration periods could give better insight into long-term effects.

\section{Conclusions}

- Responses of enzyme activities involved in immune and detoxification mechanisms in juveniles of the Pacific oyster $C$. gigas were highly variable depending on the treatment, the time and the tissue that was studied, highlighting the importance of carrying out studies in different tissues and with multiple enzymes involved in crucial biological responses.

- Enzyme activities were generally inhibited in the gills and plasma, while they were generally activated in the mantle and haemocytes, suggesting that the gills and the plasma are sensitive compartments in C. gigas and that the mantle and the haemocytes are likely to play an important role in protection against PAHs.

- Among the various parameters and during the exposure period, enzyme activities in the digestive gland, mantle and haemocytes were generally positively correlated with PAH body burdens. Enzyme activities in the gills and plasma were generally negatively correlated with PAH body burdens, suggesting potential suppressive effects of pollutants in immune and/or detoxification mechanisms through the inhibition of enzyme activities involved in these biological responses.

- Finally, the presence of dispersants or of chemically dispersed oil modulates different biological responses in $C$. gigas. These results raise questions as to the potential effects of chemically dispersed oil in nearshore areas on immune and/or detoxification responses for this estuarine species, such as in the case of the Deepwater Horizon oil spill, in which a high percentage of oil was dispersed in the water column, with a large number of unknowns on the long-term impact of the oil-dispersant association.

Acknowledgements: This study was supported by a $\mathrm{PhD}$ grant for A. Luna-Acosta from the Conseil Général de la Charente-Maritime. The Programme Ecotechnologies et Développement 
Durable (PRECODD) of the Agence Nationale de la Recherche (ANR) and especially M. Girin and G. Le Lann are acknowledged for financial support for the project 'DISCOBIOL' ("Dispersants et technique de lutte en milieux côtiers : effets biologiques et apports à la réglementation"), managed by F. X. Merlin. The authors also acknowledge Total Fluides for providing chemicals. Special thanks go to M. Menguy and M. Pommier for their help and assistance during the study and during the experimental procedures. The authors thank also S. Ferguson (Alba Traduction, Quimper, France) for her revision of the English language. Finally, the authors specially acknowledge Dr. T. Caquet and Dr. P-G. Sauriau for their help and assistance for statistical analysis.

\section{References}

Anderson, J., Neff, J., Cox, B., Tatum, H., Hightower, G., 1974. Characteristics of dispersions and watersoluble extracts of crude and refined oils and their toxicity to estuarine crustaceans and fish. Marine Biology 27, 75-88.

ASTM Committee, 1984. Oil spill chemical dispersants: research, experience, and recommendations: a symposium, ASTM International, p. 465.

Baca, B., Ward, G., Lane, C., Schuler, P., 2006. Net environmental benefit analysis (NEBA) of dispersed oil on near shore tropical ecosystems derived from the 20 years 'tropics' field study, Proceedings of the International Oil Spill Conference, London.

Bado-Nilles, A., Quentel, C., Auffret, M., Le Floch, S., Gagnaire, B., Renault, T., Thomas-Guyon, H., 2008. Immune effects of HFO on European sea bass, Dicentrarchus labrax, and Pacific oyster, Crassostrea gigas. Ecotoxicology and Environmental Safety 72, 1446-1454.

Bado-Nilles, A., Renault, T., Faury, N., Le Floch, S., Quentel, C., Auffret, M., Thomas-Guyon, H., 2010. In vivo effects of LCO soluble fraction on immune-related functions and gene transcription in the Pacific oyster, Crassostrea gigas (Thunberg). Aquatic Toxicology 97(3), 196-203. 
Baumard, P., Budzinski, H., Garrigues, P., 1997. Analytical procedure for the analysis of PAHs in

571 biological tissues by gas chromatography coupled to mass spectrometry: application to mussels.

572 Fresenius' Journal of Analytical Chemistry 359(6), 502-509.

573 Baussant, T., Sanni, S., Skadsheim, A., Jonsson, G., Borseth, J., Gaudebert, B., 2001. Bioaccumulation of 574 polycyclic aromatic compounds: 2. Modeling bioaccumulation in marine organisms chronically exposed 575 to dispersed oil. Environmental Toxicology and Chemistry 20(6), 1185-1195.

576 Berthou, F., Balouët, G., Bodennec, G., Marchand, M., 1987. The occurrence of hydrocarbons and 577 histopathological abnormalities in oysters for seven years following the wreck of the Amoco Cadiz in 578 Brittany (France). Marine Environmental Research 23(2), 103-133.

579 Borg, D., Schaich, K., 1983. Cytotoxicity from coupled redox cycling of autoxidizing xenobiotics and metals. Israel Journal of Chemistry 24(1), 38-53.

581 Boutet, I., Tanguy, A., Moraga, D., 2004. Response of the Pacific oyster Crassostrea gigas to 582 hydrocarbon contamination under experimental conditions. Gene 329(1), 147-157.

583 Canevari, G., 1973. Development of the 'next generation' chemical dispersants, Prevention and control of 584 oil spills, Washington DC, p. 231-240.

585 Cazenave, J., Bistoni, M., Zwirnmann, E., Wunderlin, D., Wiegand, C., 2006. Attenuating effects of 586 natural organic matter on microcystin toxicity in zebra fish (Danio rerio) embryos - benefits and costs of 587 microcystin detoxication. Environmental Toxicology 21(1), 22-32.

588 Chafai-El Alaoui, S., 1994. Etude de quelques aspects de la contamination métallique chez certains 589 mollusques et poissons marins: Etude environnementale (côte atlantique marocaine) et approche 590 expérimentale, Faculté des Sciences Semlalia. Cadi Ayyad, Marrakech, p. 155.

591 Cheng, T., 1981. Invertebrate blood cells. Academic Press, London, p. 233-300.

592 Cheung, C.C.C., Zheng, G.J., Li, A.M.Y., Richardson, B.J., Lam, P.K.S., 2001. Relationships between 593 tissue concentrations of polycyclic aromatic hydrocarbons and antioxidative responses of marine mussels, 594 Perna viridis. Aquatic Toxicology 52(3-4), 189-203.

595 Chu, F., Soudant, P., Hale, R., 2003. Relationship between PCB accumulation and reproductive output in 596 conditioned oysters Crassostrea virginica fed a contaminated algal diet. Aquatic Toxicology 65293-307. 
Dodor, D.E., Hwang, H.-M., Ekunwe, S.I.N., 2004. Oxidation of anthracene and benzo[a]pyrene by immobilized laccase from Trametes versicolor. Enzyme and Microbial Technology 35(2-3), 210-217.

Fossati, P., Prencipe, L., Berti, G., 1980. Use of 3,5-dichloro-2-hydroxybenzenesulfonic acid/4aminophenazone chromogenic system in direct enzymic assay of uric acid in serum and urine. Clinical Chemistry 26, 227-231.

Frouin, H., Pellerin, J., Fournier, M., Pelletier, E., Richard, P., Pichaud, N., Rouleau, C., Garnerot, F., 2007. Physiological effects of polycyclic aromatic hydrocarbons on soft-shell clam Mya arenaria. Aquatic Toxicology 82(2), 120-134.

Gilfillan, E., Page, D., Hanson, S., Foster, J., Hotham, J., Vallas, D., Gerber, R., 1984. Effects of test spills of chemically dispersed and nondispersed oil on the activity of aspartate amino-transferase and glucose-6-phosphate dehydrogenase in two intertidal bivalves, Mya arenaria and Mytilus edulis, in: ASTM International (Ed.), Oil spill chemical dispersants: research, experience, and recommendations: a symposium, p. 299-313.

Giron-Perez, M.I., 2010. Relationships between innate immunity in bivalve molluscs and environmental pollution. Invertebrate Survival Journal 7, 149-156.

Gopalakrishnan, S., Thilagam, H., Huang, W.-B., Wang, K.-J., 2009. Immunomodulation in the marine gastropod Haliotis diversicolor exposed to benzo(a)pyrene. Chemosphere 75(3), 389-397.

Grundy, M., Moore, M., Howell, S., Ratcliffe, N., 1996. Phagocytic reduction and effects on lysosomal membranes by polycylic aromatic hydrocarbons, in haemocytes of Mytilus edulis. Aquatic Toxicology 34, 273-290.

Hannam, M.L., Bamber, S.D., Moody, J.A., Galloway, T.S., Jones, M.B., 2009. Immune function in the Arctic Scallop, Chlamys islandica, following dispersed oil exposure. Aquatic Toxicology 92(3), 187-194. Huggett, R., Kimerle, R., Mehrle Jr., P., 1992. Biomarkers: biochemical, physiological and histological makers of anthropogenic stress, Lewis, Boca Raton, p. 347.

Kappus, H., 1985. Lipid peroxidation: mechanisms, analysis, enzymology and biological relevance, Sies, H. (Ed.), Academic Press, London, p. 273-310. 

neuroendocrine changes increase the susceptibility of juvenile oysters (Crassostrea gigas) to Vibrio splendidus. General and Comparative Endocrinology 67(5), 2304-2309. amphipod, Pontoporeia hoyi. Environmental Toxicology and Chemistry 10(1), 1019-1028.

Leps, J. S., Smilauer, P. 1999. Multivariate analysis of ecological data: course material. Ceske

Lessard, R.R., DeMarco, G., 2000. The significance of oil spill dispersants. Spill Science and Technology

Li, M., Garrett, C., 1998. The relationship between oil droplet size and upper ocean turbulence. Marine Pollution Bulletin 36(12), 961-970.

Luna-Acosta, A., Bustamante, P., Godefroy, J., Fruitier-Arnaudin, I., Thomas-Guyon, H., 2010 a. Seasonal variation of pollution biomarkers to assess the impact on health status of juvenile Pacific oysters Crassostrea gigas exposed in situ. Environmental Science and Pollution Research 17(4), 999-1008. 2010b. First evidence of laccase activity in the Pacific oyster Crassostrea gigas. Fish and Shellfish Immunology 28(4), 719-726.

640 Luna-Gonzalez, A., Maeda-Martinez, A., Ascencio-Valle, F., Robles-Mungaray, M., 2004. Ontogenic 641 variations of hydrolytic enzymes in the Pacific oyster Crassostrea gigas. Fish and Shellfish Immunology, $642 \quad 16,287-294$.

643 Lunel, T., 1995. The Braer oil spill: oil fate governed by dispersion, International oil spill conference, Long Beach, California, USA.

645 Marchand, R., 1998. Marketing of solid waste management services in Tingloy, the Philippines, UWEP 646 Working Document 9.

647 McCormick-Ray, M., 1987. Hemocytes of Mytilus edulis affected by Prudhoe Bay crude oil emulsion. 648 Marine Environmental Research 22(2), 107-122. 

species. Comparative Biochemistry and Physiology B 85(3), 581-584.

651

652

653

654

655

656

657

658

659

660

661

662

663

664

665

666

667

668

669

670

671

672

673

674

McLeese, D.W., Burridge, L.E., 1987. Comparative accumulation of PAHs in four marine invertebrates, in: Capuzzo, J., Kester, D. (Eds.), Oceanic processes in marine pollution. Robert E. Krieger Publishing Company, Malobar, Florida, p. 109-118.

Meador, J., 2003. Bioaccumulation of PAHs in marine invertebrates, in: Douben, P. (Ed.), PAHs: An ecological perspective. John Wiley and son, NY, USA, p. 392.

Michel, J., Henry, C.B., 1997. Oil uptake and depuration in oysters after use of dispersants in shallow water in El Salvador. Spill Science and Technology Bulletin 4(2), 57-70.

Moore, M.N., 1985. Cellular responses to pollutants. Marine Pollution Bulletin 16(4), 134-139.

NCR (National Research Council), 2003. Oil in the Sea III: Inputs, Fates and Effects. The National Academies Press, Washington DC, p. 265

Neff, J.M., 2002. Bioaccumulation in marine organisms: effect of contaminants from oil well produced water. Elsevier Science, Oxford, p. 452.

Neumann, N.F., Stafford, J.L., Barreda, D., Ainsworth, A.J., Belosevic, M., 2001. Antimicrobial mechanisms of fish phagocytes and their role in host defense. Developmental \& Comparative Immunology 25(8-9), 807-825.

Oliver, L.M., Fisher, W.S., Volety, A.K., Malaeb, Z., 2003. Greater hemocyte bactericidal activity in oysters (Crassostrea virginica) from a relatively contaminated site in Pensacola Bay, Florida 64, 363-373.

Orbea, A., Ortiz-Zarragoitia, M., Solé, M., Porte, C., Cajaraville, M.P., 2002. Antioxidant enzymes and peroxisome proliferation in relation to contaminant body burdens of PAHs and PCBs in bivalve molluscs, crabs and fish from the Urdaibai and Plentzia estuaries (Bay of Biscay). Aquatic Toxicology 58(1-2), 7598.

Ordas, M.C., Albaiges, J., Bayona, J.M., Ordas, A., Figueras, A., 2003. Assessment of in vivo effects of the Prestige fuel oil spill on the Mediterranean mussel immune system. Archives of Environmental Contamination and Toxicology 52, 200-206. 

a chemically-dispersed oil and a whole oil on a near-shore environment. Water Research 34(9), 2507-

677

678

679

680

681

682

683

684

685

686

687

688

689

690

691

692

693

694

695

696

697

698

699

700

701 2516.

Perdue, J., Beattie, J., Chew, K., 1981. Some relationships between gametogenic cycle and summer mortality phenomenon in the Pacific oyster (Crassostrea gigas) in Washington State. Journal of Shellfish Research 1(1), 9-16.

Ramachandran, S.D., Hodson, P.V., Khan, C.W., Lee, K., 2004. Oil dispersant increases PAH uptake by fish exposed to crude oil. Ecotoxicology and Environmental Safety 59(3), 300-308.

Richardson, B.J., Mak, E., De Luca-Abbott, S.B., Martin, M., McClellan, K., Lam, P.K.S., 2008. Antioxidant responses to polycyclic aromatic hydrocarbons and organochlorine pesticides in green-lipped mussels (Perna viridis): Do mussels "integrate" biomarker responses? Marine Pollution Bulletin 57(612), 503-514.

Roy, G., Vuillemin, R., Guyomarch, J., 2005. On-site determination of polynuclear aromatic hydrocarbons in seawater by stir bar sorptive extraction (SBSE) and thermal desorption GC-MS. Talanta $66,540-546$.

Shafir, S., Van Rijn, J., Rinkevich, B., 2007. Short- and long-term toxicity of crude oil and oil dispersants to two representative coral species. Environmental Science and Technology 41(15), 5571-5574.

Singer, M., Aurand, D., Bragin, G., Clark, J., Coelho, G., Sowby, M., Tjeerdema, R., 2000. Standardization of the preparation and quantitation of water-accommodated fractions of petroleum for toxicity testing. Marine Pollution Bulletin. 40(11), 1007-1016.

Smith, P., Krohn, R., Hermanson, G., Mallia, A., Gartner, F., Provenzano, M., Fujimoto, E., Goeke, N., Olson, B., Klenk, D., 1985. Measurement of protein using bicinchoninic acid. Analytical Biochemistry 15076-85.

Söderhäll, K., Cerenius, L., 1998. Role of the prophenoloxidase-activating system in invertebrate immunity. Current Opinion in Immunology 10(1), 23-28.

Sole, M., Porte, C., Albaiges, J., 1995. The use of biomarkers for assessing the effects of organic pollution in mussels. Science of the Total Environment 159(2-3), 147-153. 
702 Stabili, L., Pagliara, P., 2009. Effect of zinc on lysozyme-like activity of the seastar Marthasterias 703 glacialis (Echinodermata, Asteroidea) mucus. Journal of Invertebrate Pathology 100(3), 189-192.

704 Thiagarajan, R., Gopalakrishnan, S., Thilagam, H., 2006. Immunomodulation the marine green mussel 705 Perna viridis exposed to sub-lethal concentrations of $\mathrm{Cu}$ and $\mathrm{Hg}$. Archives of Environmental 706 Contamination and Toxicology 51(3), 392-399.

707 Tryphonas, H., Fournier, M., Blakley, B., Smits, J., Brousseau, P., 2005. Investigative 708 Immunotoxicology. Informa Healthcare, London, p. 480.

709 Venosa, A.D., Zhu, X., 2003. Biodegradation of crude oil contaminating marine shorelines and freshwater 710 wetlands. Spill Science and Technology Bulletin 8(2), 163-178.

711 Verlecar, X.N., Jena, K.B., Chainy, G.B.N., 2007. Biochemical markers of oxidative stress in Perna

712 viridis exposed to mercury and temperature. Chemico-Biological Interactions 167(3), 219-226.

713 Winston, G.W., 1991. Oxidants and antioxidants in aquatic animals. Comparative Biochemistry and 714 Physiology C 100(1-2), 173-176.

715 Zar, J., 1984. Biostatistical analysis, Prentice-Hall, New Jersey, p. 718. 
Figure 1. Proportion ( $\%$, mean $\pm \mathrm{SD}, \mathrm{n}=3$ ) of the main PAHs contained in oyster tissues after 2 days of exposure to chemical dispersion (CD), mechanical dispersion (MD), water soluble fraction (WSF) and dispersant (D) treatments, followed by 15 days of depuration. PAHs: polycyclic aromatic hydrocarbons; NaF: naphthalene; Ac: acenaphtylene; Fl: fluorene; Fen: phenanthrene; Ant: anthracene; DBT: dibenzothiophene.

\section{Exposure}
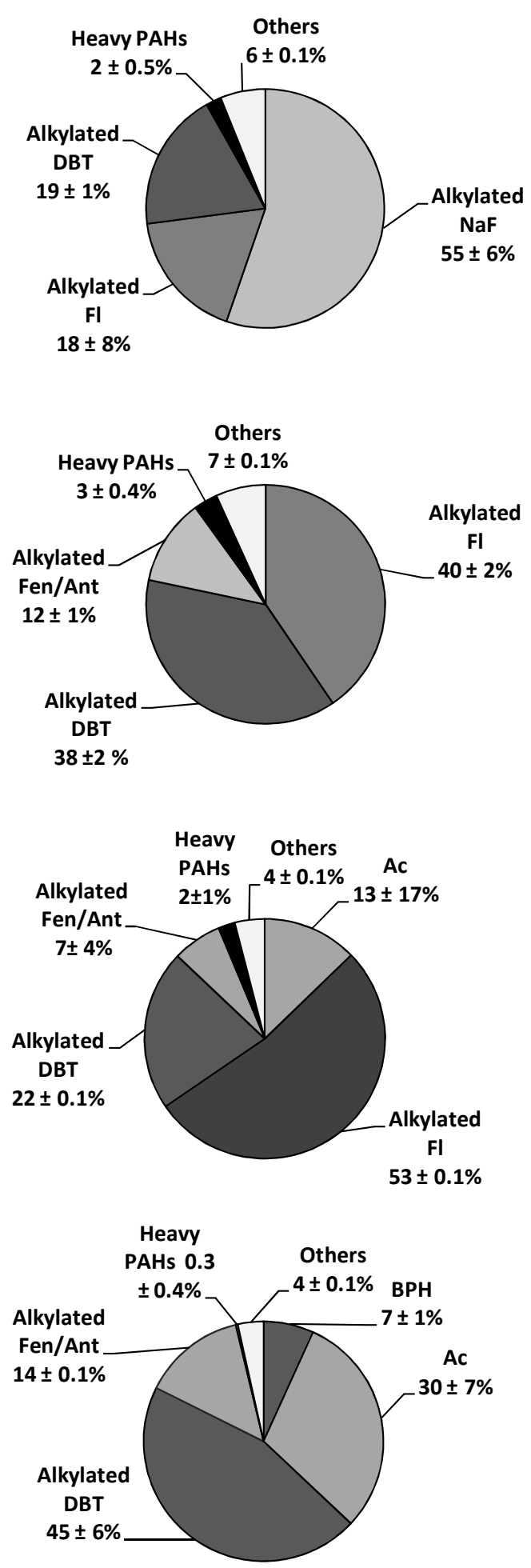

\section{Depuration}

CD

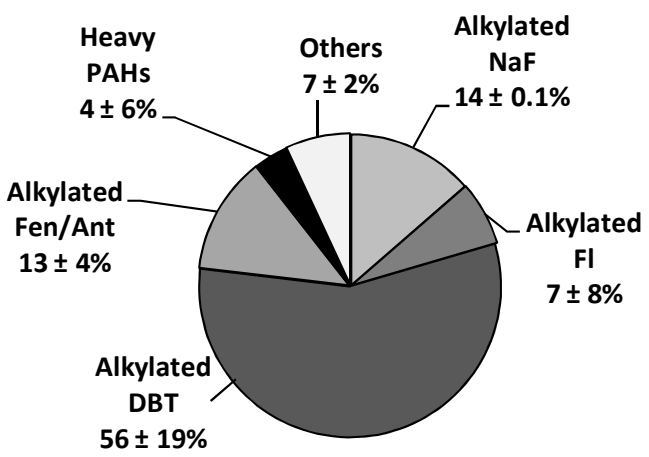

MD

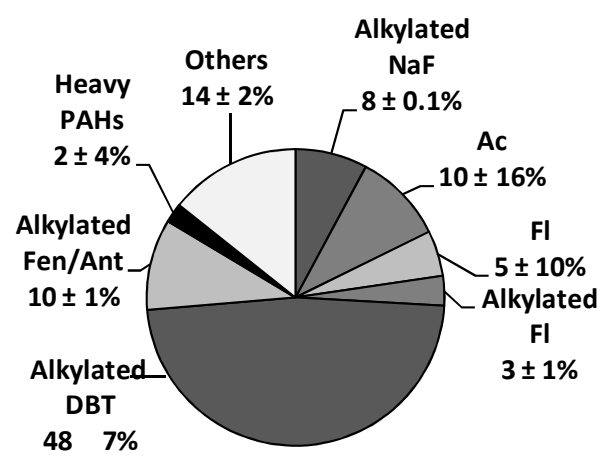

WSF

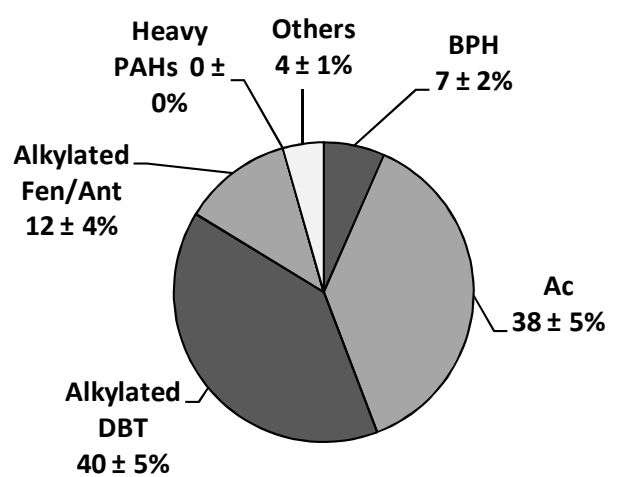

D

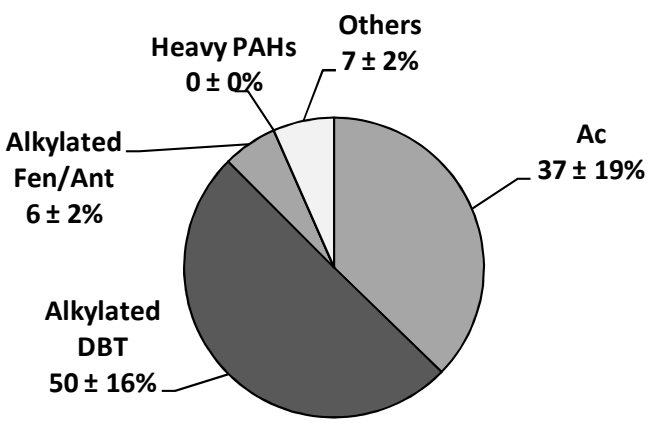


Figure 2. Superoxide dismutase activity in the gills, digestive gland, mantle, plasma and haemocyte lysate supernatant (HLS) in C. gigas after 2 days of exposure to chemical dispersion (CD), mechanical dispersion (MD), water soluble fraction (WSF) and dispersant (D) treatments, followed by 15 days of depuration. Data are expressed as mean \pm SD U.mg prot $^{-1}$, $n=9$ (i.e. 3 sample replicates from 3 experiment replicates). For clarity of results, only significant differences between control and treatment and for a given time (after $2 \mathrm{~d}$ of exposure or after $15 \mathrm{~d}$ of depuration) are shown; $* \mathrm{p}<0.05, * * \mathrm{p}<0.01, * * * \mathrm{p}<0.001$.

\section{Gills}

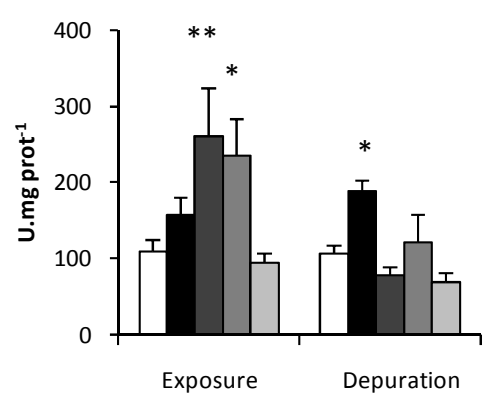

Digestive gland

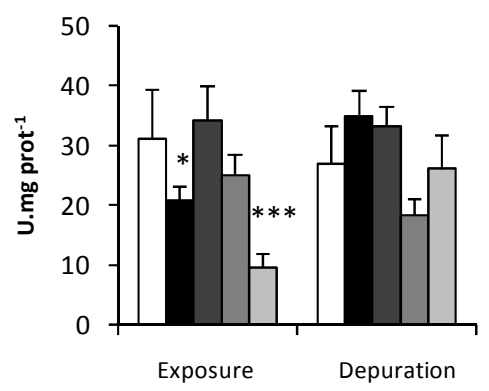

Mantle

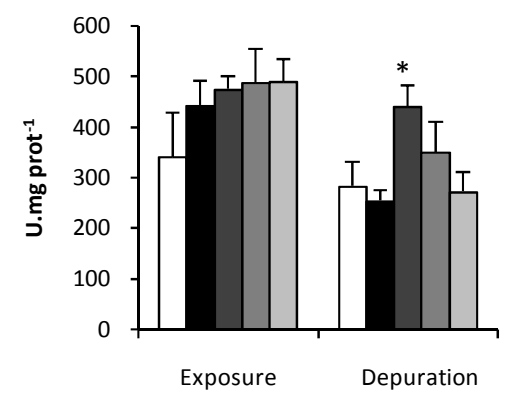

Plasma

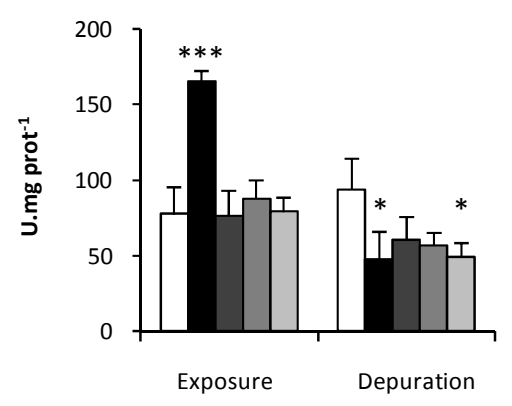

HLS

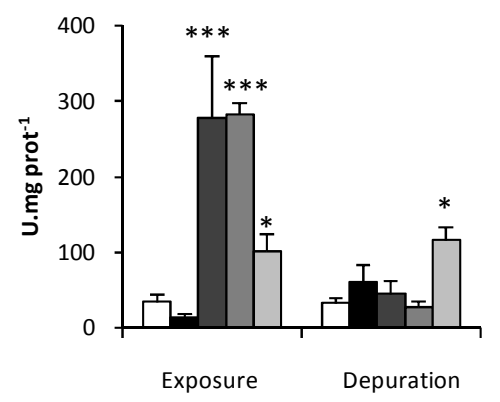


Figure 3. Catalase activity in the gills, digestive gland, mantle, plasma and haemocyte lysate supernatant (HLS) in C. gigas after 2 days of exposure to chemical dispersion (CD), mechanical dispersion (MD), water soluble fraction (WSF) and dispersant (D) treatments, followed by 15 days of depuration. Data are expressed as mean \pm SD U.mg prot ${ }^{-1}, n=9$ (i.e. 3 sample replicates from 3 experiment replicates). For clarity of results, only significant differences between control and treatment and for a given time (after $2 \mathrm{~d}$ of exposure or after $15 \mathrm{~d}$ of depuration) are shown; $* \mathrm{p}<0.05, * * \mathrm{p}<0.01, * * * \mathrm{p}<0.001$.

Gills

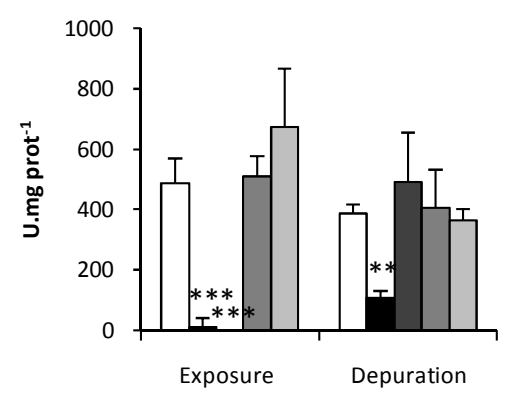

Digestive gland

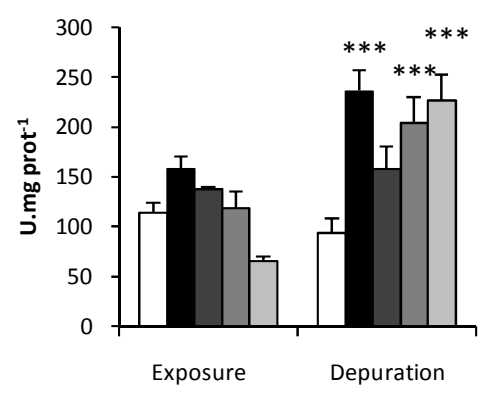

Mantle

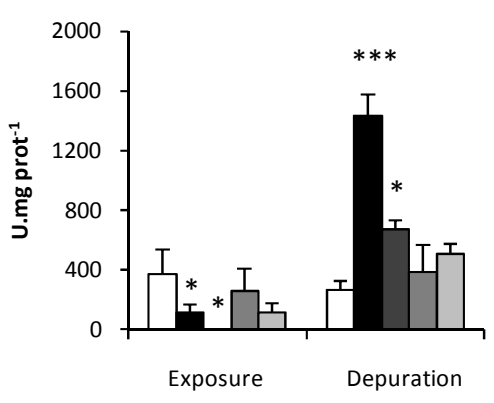

Plasma

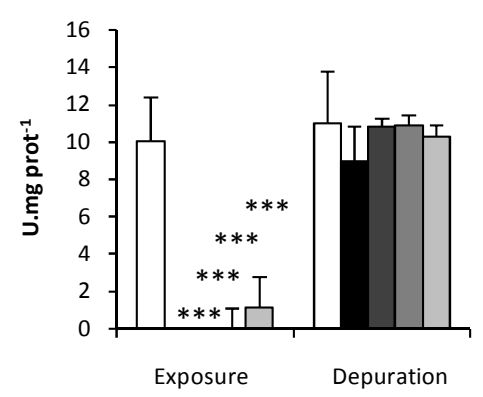

HLS

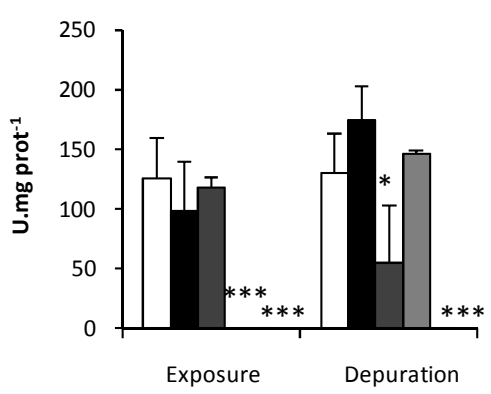


Figure 4. Glutathione peroxidase activity in the gills, digestive gland, mantle, plasma and haemocyte lysate supernatant (HLS) in C. gigas after 2 days of exposure to chemical dispersion (CD), mechanical dispersion (MD), water soluble fraction (WSF) and dispersant (D) treatments, followed by 15 days of depuration. Data are expressed as mean \pm SD U.mg $\operatorname{prot}^{-1}$, $n=9$ (i.e. 3 sample replicates from 3 experiment replicates). For clarity of results, only significant differences between control and treatment and for a given time (after $2 \mathrm{~d}$ of exposure or after $15 \mathrm{~d}$ of depuration) are shown; $* \mathrm{p}<0.05, * *<\mathrm{p} 0.01, * * * \mathrm{p}<0.001$.

\section{Gills}

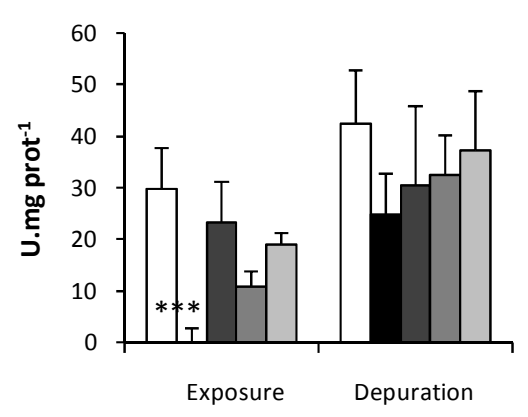

Digestive gland

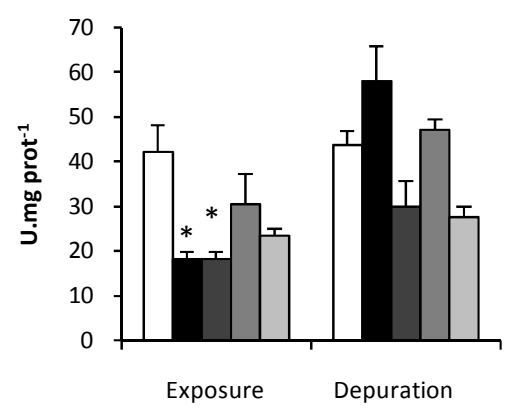

Mantle

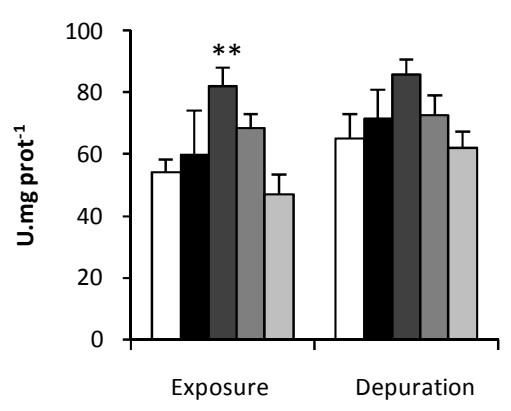

Plasma

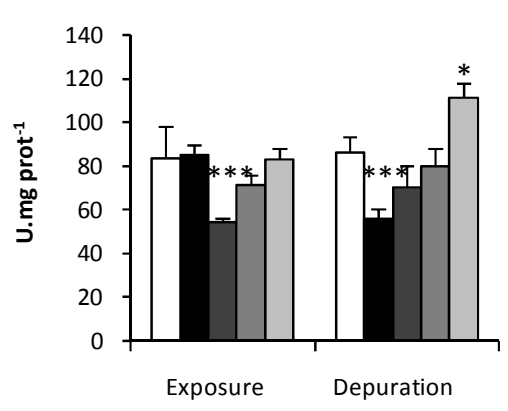

HLS

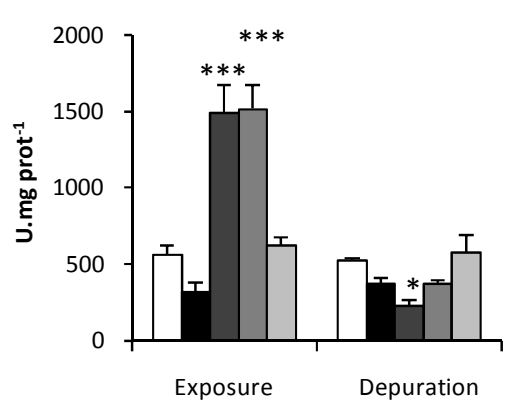


Figure 5. Catecholase-type phenoloxidase activity in the gills, digestive gland, mantle, plasma and haemocyte lysate supernatant (HLS) in C. gigas after 2 days of exposure to chemical dispersion (CD), mechanical dispersion (MD), water soluble fraction (WSF) and dispersant (D) treatments, followed by 15 days of depuration. Data are expressed as mean \pm SD U.mg prot ${ }^{-1}$, $n=9$ (i.e. 3 sample replicates from 3 experiment replicates). For clarity of results, only significant differences between control and treatment and for a given time (after $2 \mathrm{~d}$ of exposure or after $15 \mathrm{~d}$ of depuration) are shown. For the mantle, the enzyme activity was not affected by both treatment and period, but only by treatment. Therefore, results represent the mean of overall data from exposure and depuration periods. $* \mathrm{p}<0.05, * * \mathrm{p}<0.01, * * * \mathrm{p}<0.001$.

\section{Gills}

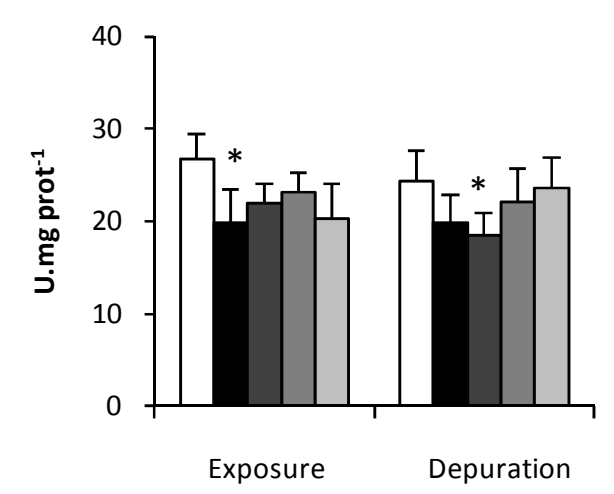

Plasma

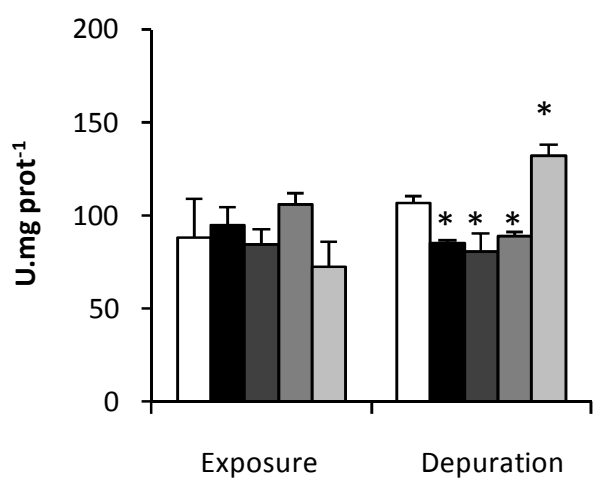

Mantle

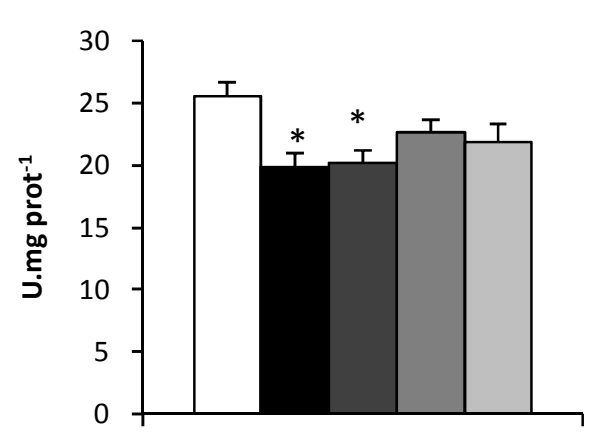

HLS

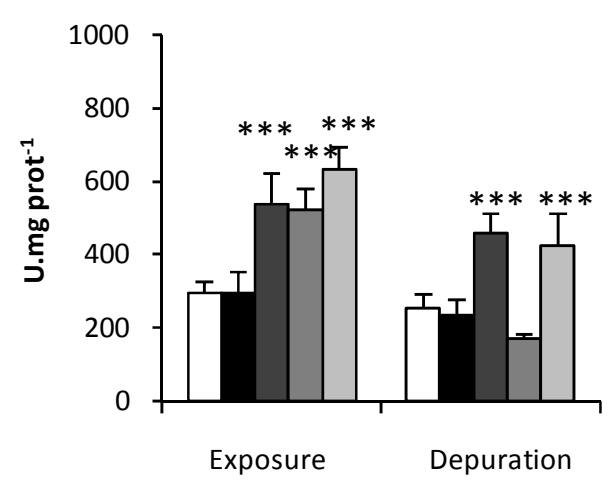


Figure 6. Laccase-type phenoloxidase activity in the gills, digestive gland, mantle, plasma and haemocyte lysate supernatant (HLS) in C. gigas after 2 days of exposure to chemical dispersion (CD), mechanical dispersion (MD), water soluble fraction (WSF) and dispersant (D) treatments, followed by 15 days of depuration. Data are expressed as mean \pm SD U.mg $\operatorname{prot}^{-1}, \mathrm{n}=9$ (i.e. 3 sample replicates from 3 experiment replicates). For clarity of results, only significant differences between control and treatment and for a given time (after $2 \mathrm{~d}$ of exposure or after $15 \mathrm{~d}$ of depuration) are shown. For the mantle, the enzyme activity was not affected by both treatment and period, but only by treatment. Therefore, results represent the mean of overall data from exposure and depuration periods. $* \mathrm{p}<0.05, * * \mathrm{p}<0.01, * * * \mathrm{p}<0.001$.

\section{Gills}

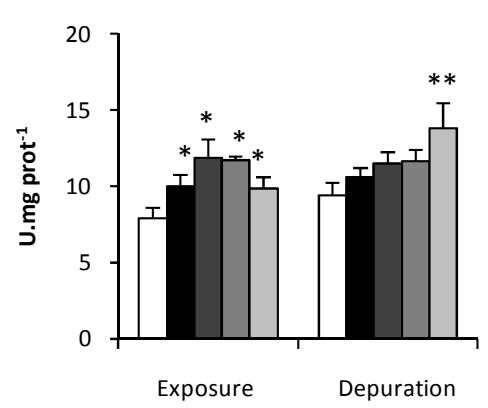

Digestive gland

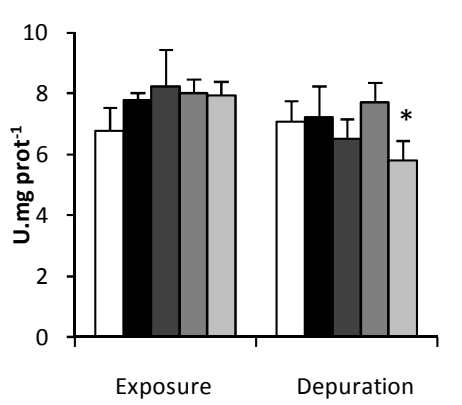

Mantle

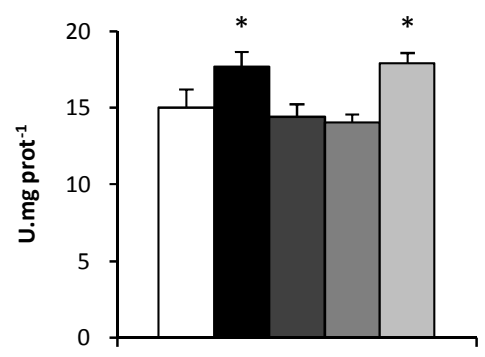

\section{Plasma}

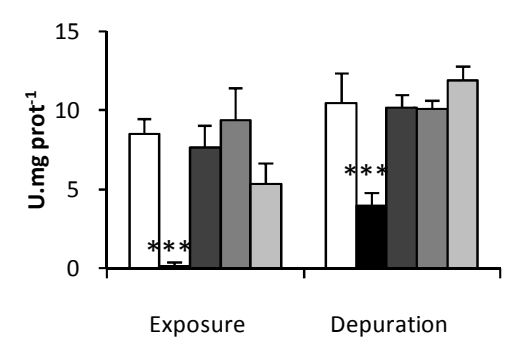

HLS

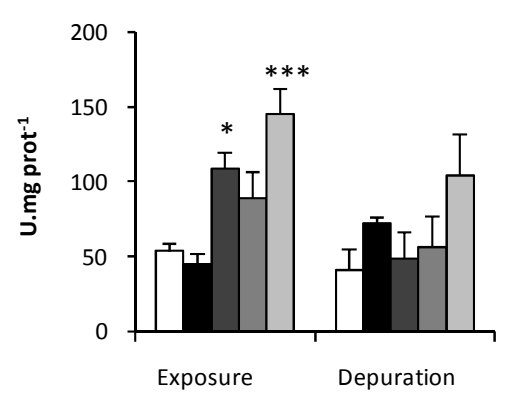


Figure 7. Lysozyme activity in the digestive gland and the mantle in $C$. gigas after 2 days of exposure to chemical dispersion (CD), mechanical dispersion (MD), water soluble fraction (WSF) and dispersant (D) treatments, followed by 15 days of depuration. Data are expressed as mean \pm SD U.mg prot $^{-1}$, n=9 (i.e. 3 sample replicates from 3 experiment replicates). For clarity of results, only significant differences between control and $* * * \mathrm{p}<0.001$.

\section{Digestive gland}

Mantle
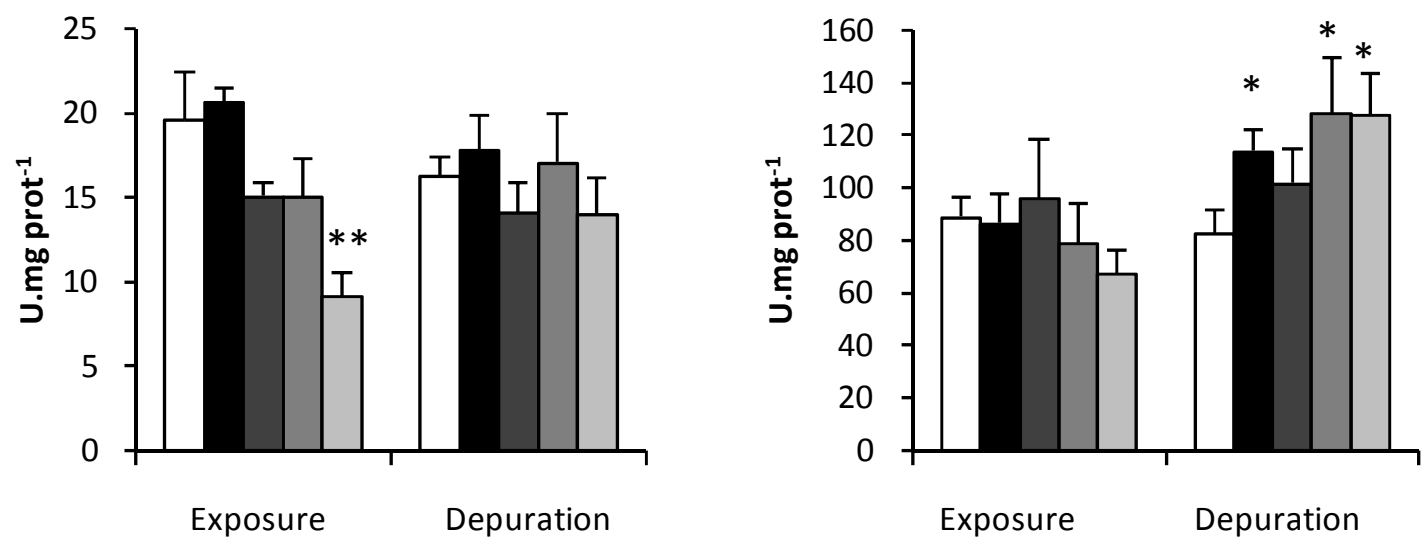


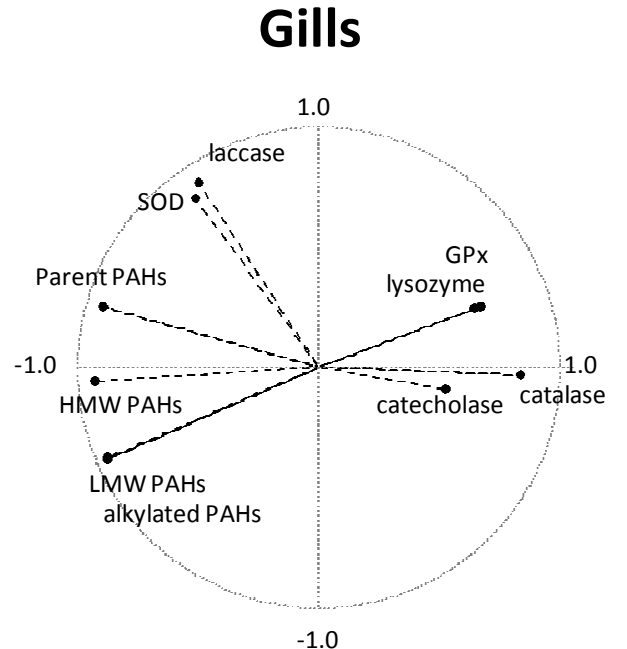

\section{Digestive gland}

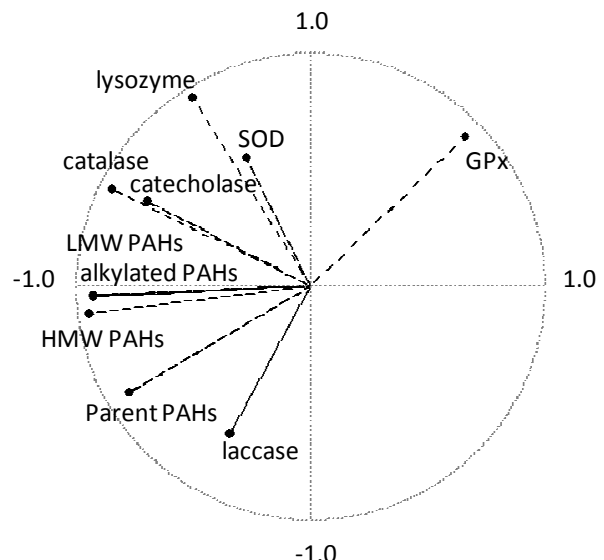

Mantle

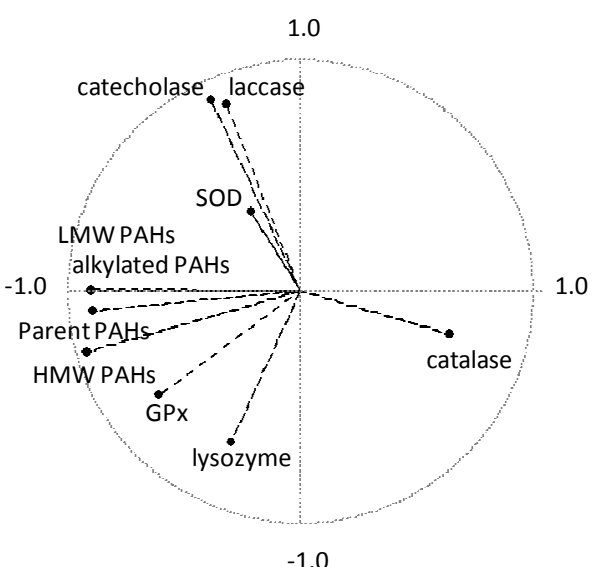

\section{Plasma}

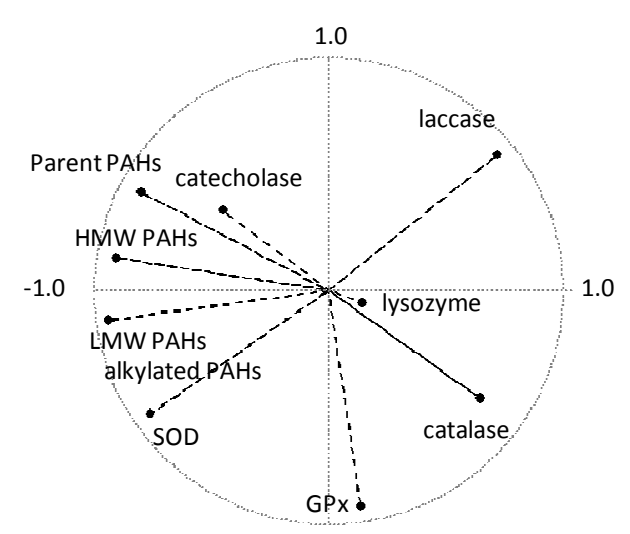

$-1.0$

\section{HLS}

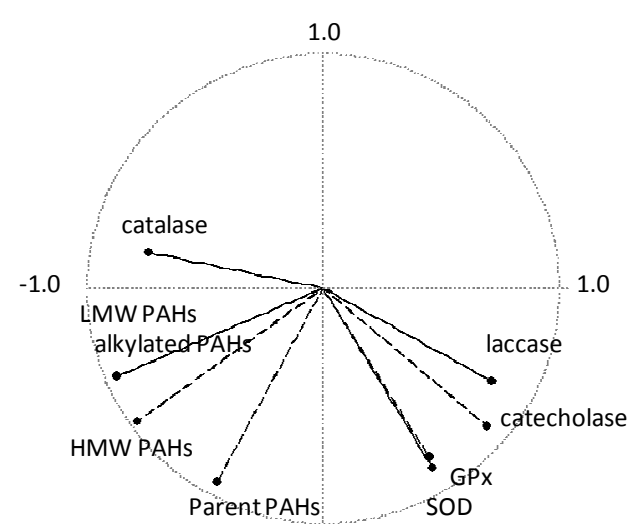

$-1.0$ 
Table 1. Experimental conditions used in the study. CD: chemical dispersion, MD: mechanical dispersion, WSF: water soluble fraction and D: dispersant. BAL 110: Brut Arabian Light crude oil topped at $110^{\circ} \mathrm{C}$.

\begin{tabular}{|c|c|c|}
\cline { 2 - 3 } \multicolumn{1}{c|}{} & \multicolumn{2}{c|}{ Quantity of the product added to the water column $\left(\mathrm{mg} . \mathrm{I}^{-1}\right)^{\#}$} \\
\cline { 2 - 3 } \multicolumn{1}{c|}{} & BAL 110 & Dispersant \\
\hline Control & 0 & 0 \\
\hline CD & 67 & 4 \\
\hline MD & 67 & 0 \\
\hline WSF & 67 & 0 \\
\hline D ( (internal control of CD) & 0 & 4 \\
\hline
\end{tabular}
before introducing animals in the tanks 
Table 2 Relationships between enzyme activities in tissues and haemolymphatic compartments and body burdens of the various PAH categories measured in the whole organism.

785

\begin{tabular}{|c|c|c|c|c|c|}
\hline & Gills & Digestive gland & Mantle & Plasma & HLS \\
\hline \multicolumn{6}{|c|}{ Significance of enzyme activities-PAH body burden relationship (RDA; Monte Carlo test, $p$-value) } \\
\hline & 0.002 & 0.009 & 0.001 & 0.021 & 0.025 \\
\hline \multicolumn{6}{|c|}{ Amount of total variation in enzyme activities explained by PAH body burdens (\%) } \\
\hline & 48.6 & 42.5 & 43.3 & 38.7 & 43.5 \\
\hline \multicolumn{6}{|c|}{ Correlation with RDA 1st axis } \\
\hline HMW PAHs & 0.778 & 0.822 & 0.382 & 0.673 & 0.183 \\
\hline LMW PAHs & 0.631 & 0.756 & 0.620 & 0.776 & 0.369 \\
\hline Parent PAHs & 0.871 & 0.618 & 0.873 & 0.623 & -0.216 \\
\hline Alkylated PAHs & 0.630 & 0.758 & 0.380 & 0.774 & 0.373 \\
\hline \multicolumn{6}{|c|}{ Trend with increasing body burden of the various PAH categories, i.e. HMW, LMW, parent and alkylated PAHs } \\
\hline SOD & $\pi$ & $\lambda$ & $\pi$ & $\pi$ & $\boldsymbol{y}(\boldsymbol{\pi})^{\mathrm{a}}$ \\
\hline Catalase & $\mathbf{y}$ & 入 & $\mathbf{y}$ & $\mathbf{y}$ & $\boldsymbol{\lambda}(\mathbf{y})$ \\
\hline GPx & ע & ע & $\pi$ & ע & $\boldsymbol{y}(\boldsymbol{\pi})$ \\
\hline Catecholase & $\mathbf{y}$ & $\pi$ & $\pi$ & $\pi$ & $\boldsymbol{y}(\boldsymbol{\lambda})$ \\
\hline Laccase & $\pi$ & $\pi$ & $y$ & $y$ & $\boldsymbol{y}(\boldsymbol{\pi})$ \\
\hline Lysozyme & $y$ & $\pi$ & $\pi$ & $y$ & No data \\
\hline
\end{tabular}

a The arrows between parenthesis show the trend associated with body burden of parent PAHs 